\title{
Characterization and source apportionment of submicron aerosol with aerosol mass spectrometer during the PRIDE-PRD 2006 campaign
}

\author{
R. Xiao ${ }^{1}$, N. Takegawa ${ }^{2}$, M. Zheng ${ }^{1}$, Y. Kondo ${ }^{2}$, Y. Miyazaki ${ }^{2,3}$, T. Miyakawa ${ }^{2}$, M. Hu ${ }^{1}$, M. Shao ${ }^{1}$, L. Zeng ${ }^{1}$, Y. Gong ${ }^{4}$, \\ K. Lu ${ }^{1}$, Z. Deng ${ }^{1}$, Y. Zhao ${ }^{5}$, and Y. H. Zhang ${ }^{1}$ \\ ${ }^{1}$ State Key Joint Laboratory of Environmental Simulation and Pollution Control, College of Environmental Sciences and \\ Engineering, Peking University, Beijing, China \\ ${ }^{2}$ Research Center for Advanced Science and Technology, University of Tokyo, Tokyo, Japan \\ ${ }^{3}$ Institute of Low Temperature Science, Hokkaido University, Sapporo, Japan \\ ${ }^{4}$ Research Institute of Chemical Defence, Beijing, China \\ ${ }^{5}$ Air Quality Research Center, University of California, Davis, California, USA
}

Received: 19 December 2010 - Published in Atmos. Chem. Phys. Discuss.: 19 January 2011

Revised: 8 June 2011 - Accepted: 20 June 2011 - Published: 18 July 2011

\begin{abstract}
Size-resolved chemical compositions of nonrefractory submicron aerosol were measured using an Aerodyne quadrupole aerosol mass spectrometer (Q-AMS) at the rural site Back Garden (BG), located $\sim 50 \mathrm{~km}$ northwest of Guangzhou in July 2006. This paper characterized the submicron aerosol particles of regional air pollution in Pearl River Delta (PRD) in the southern China. Organics and sulfate dominated the submicron aerosol compositions, with average mass concentrations of $11.8 \pm 8.4 \mu^{-3} \mathrm{~m}^{-3}$ and $13.5 \pm 8.7 \mu \mathrm{g} \mathrm{m}^{-3}$, respectively. Unlike other air masses, the air masses originated from Southeast-South and passing through the PRD urban areas exhibited distinct bimodal size distribution characteristics for both organics and sulfate: the first mode peaked at vacuum aerodynamic diameters $\left(D_{\text {va }}\right) \sim 200 \mathrm{~nm}$ and the second mode occurred at $D_{\text {va }}$ from $300-700 \mathrm{~nm}$. With the information from AMS, it was found from this study that the first mode of organics in PRD regional air masses was contributed by both secondary organic aerosol formation and combustion-related emissions, which is different from most findings in other urban areas (first mode of organics primarily from combustionrelated emissions). The analysis of AMS mass spectra data by positive matrix factorization (PMF) model identified three sources of submicron organic aerosol including hydrocarbon-like organic aerosol (HOA), low volatility oxygenated organic aerosol (LV-OOA) and semi-volatile oxy-
\end{abstract}

genated organic aerosol (SV-OOA). The strong correlation between HOA and EC indicated primary combustion emissions as the major source of HOA while a close correlation between SV-OOA and semi-volatile secondary species nitrate as well as between LV-OOA and nonvolatile secondary species sulfate suggested secondary aerosol formation as the major source of SV-OOA and LV-OOA at the BG site. However, LV-OOA was more aged than SV-OOA as its spectra was highly correlated with the reference spectra of fulvic acid, an indicator of aged and oxygenated aerosol. The origin of HOA and OOA (the sum of LV-OOA and SV-OOA) has been further confirmed by the statistics that primary organic carbon (POC) and secondary organic carbon (SOC), estimated by the EC tracer method, were closely correlated with HOA and OOA, respectively. The results of the EC tracer method and of the PMF model revealed that primary organic aerosol (POA) constituted $\sim 34-47 \%$ of OA mass and secondary organic aerosol (SOA) constituted $\sim 53-66 \%$ of regional organic aerosol in PRD during summer season. The presence of abundant SOA was consistent with water soluble organic carbon (WSOC) results (accounting for $\sim 60 \%$ of OC on average) by Miyazaki et al. (2009) for the same campaign. OOA correlated well with WSOC at the BG site, indicating that most OOA were water soluble. More specifically, approximately $86 \%$ of LV-OOA and $61 \%$ of SV-OOA were estimated as water soluble species on the basis of carbon content comparison.

Correspondence to: $\mathrm{Y}$. H. Zhang

(yhzhang@pku.edu.cn)

Published by Copernicus Publications on behalf of the European Geosciences Union. 


\section{Introduction}

Atmospheric aerosol plays very important roles in climate change and air quality on regional and global scales (Seinfeld and Pankow, 2003). The study of aerosol particle mass concentrations, size distributions, and chemical compositions is required in order to better understand these impacts of atmospheric aerosol (McMurry, 2000). Traditionally, the information of size-resolved chemical compositions of aerosol particles was obtained through sampling particles using cascade impactors. This technique usually requires many hours of sampling and extensive analysis in the laboratory. In addition, its results are often associated with uncertainties due to artifacts from sampling and filter storage processes. Therefore, several instruments that are capable of performing continuous size-resolved measurements of aerosol composition have been developed in the past decade (Jayne et al., 2000; Jimenez et al., 2003; Middlebrook et al., 2003). Online techniques are faster, less labor intensive, and less vulnerable to artifacts introduced during sample collection and processing (Zhang et al., 2005a). One of these instruments is Aerodyne aerosol mass spectrometer (AMS) that can determine the size distribution and chemical composition of non-refractory submicron aerosol particles with time resolution of minutes (Jayne et al., 2000; Jimenez et al., 2003). Simultaneous measurements of size and chemical composition with high time resolution are particular important for the study of health impacts of submicron particles and sources of fine particulate matter in the southern China.

AMS has been deployed in a lot of field campaigns conducted in various locations and seasons including ground sites from urban areas, downwind of urban emissions, and rural/remote areas in order to characterize submicron particle properties and identify their possible sources (Zhang et al., 2005a, b, c, 2007). Sulfate and organics are commonly found as two major components in submicron aerosols in these campaigns. Previous studies have shown that organics often show bimodal size distributions at urban sites (Alfarra et al., 2004, 2007; Allan et al., 2003a, b, 2004; Jimenez et al., 2003; Kondo et al., 2007; Salcedo et al., 2006; Sun et al., 2010; Zhang et al., 2005c) with the first mode peaking around $200 \mathrm{~nm}\left(D_{\mathrm{va}}\right)$ due to combustion-related emissions (e.g. traffic) and the second mode occurring around 300$700 \mathrm{~nm}$ as a result of photochemical processing (Alfarra et al., 2004, 2007). Submicron sulfate also exhibited two modes in some cities such as Los Angeles (Hering and Friedlander, 1982; Hering et al., 1997) with the first condensation mode formed by homogeneous gas-phase reactions of $\mathrm{SO}_{2}$, and the second droplet mode attributed to in-cloud processing.

AMS organic mass spectra data are also frequently used for source apportionment of submicron organic aerosol (Zhang et al., 2005a, b; Lanz et al., 2007, 2008; Ulbrich et al., 2009, Sun et al., 2010). Lanz et al. (2007, 2008) is the first to apply positive matrix factorization (PMF) model (Paatero and Tapper, 1994; Paatero, 1997) on AMS data for source apportionment of submicron organic aerosol in Zurich, Switzerland. In their study, two subtypes of OOA that accounted for $60-69 \%$ of the measured organic aerosol mass were identified: a highly-oxygenated OA (LVOOA) that was strongly correlated with nonvolatile secondary species such as sulfate and a semi-volatile OA (SVOOA) that has a higher correlation with semi-volatile secondary species such as nitrate. The organic aerosol AMS dataset from Pittsburgh, USA was also analyzed with PMF by Ulbrich et al. (2009). In addition, several groups have tried to use methods other than PMF to deconvolve AMS organic mass spectral matrix, e.g. a custom principal component analysis technique by Zhang et al. (2005a, b) and a CO tracer method by Takegawa et al. (2006) that is conceptually similar to the EC tracer method.

Pearl River Delta (PRD) is one of the three areas in China which have experienced extremely fast economic development. Rapid urbanization and industrialization in the last few decades have introduced more complexity to air pollution issues in this area, of which high levels of ozone $\left(\mathrm{O}_{3}\right)$ and fine particulate matter $\left(\mathrm{PM}_{2.5}\right)$ are of particular concern (Zhang et al., 2008). Some research projects have been performed in PRD to investigate the chemistry of particulate pollution (Zhang et al., 2004, 2008). However, there are only very limited studies of size-resolved measurement of aerosol composition in this region (Liu, S. et al., 2008; Zhuang et al., 1999; Zheng et al., 2008). In addition, they are all filter based measurements. To our best knowledge, by far there is no study of size-resolved organic and inorganic aerosol with a time resolution of minutes in PRD. Past source apportionments of organic aerosol in this region usually rely on organic carbon (OC) to elemental carbon (EC) ratio method from offline filter measurements (Cao et al., 2003, 2004) or chemical mass balance modeling with molecular markers with 24-h filter samples (Zheng et al., 2011). Despite the lack of high time resolution, these methods could contain uncertainties since they are unable to take into account seasonal and diurnal variations in emission sources of carbonaceous aerosol (Turpin and Lim, 2001). In this study, a QAMS was deployed at the Back Garden supersite, a rural site near Guangzhou to study aerosol characteristics of regional air mass in PRD and its major sources. These objectives are achieved by studying chemical and physical properties of major components in submicron aerosol in Back Garden and conducting source apportionment of primary and secondary organic aerosol sources by applying PMF and the EC tracer method on AMS data and analyzing continuous EC/OC data, respectively. 


\section{Methods}

\subsection{Sampling site description}

The Program of Regional Integrated Experiments of Air Quality over Pearl River Delta 2006 (PRIDE-PRD 2006) campaign was conducted in the southern China in July 2006. The main objective of the campaign was to provide the regional mitigation strategies to ensure the level of air pollutants within sustainable limits through in-depth investigation of physical, chemical, and radiative properties of air pollutants. Two supersites were included in this campaign including the Guangzhou urban site $\left(23.13^{\circ} \mathrm{N}, 113.25^{\circ} \mathrm{E}\right)$ and the Back Garden rural site (BG, $\left.23.49^{\circ} \mathrm{N}, 113.03^{\circ} \mathrm{E}\right)$. Air pollution problem in Guangzhou is quite complex due to the contributions of various sources especially coal burning and vehicular emissions. Back Garden is a much less populated area at the outskirts of the densely populated center of the $\mathrm{PRD}$, thus it serves as a regional background site (Hua et al., 2008). As part of PRIDE-PRD 2006, this study focused on the BG rural site that is located $\sim 50 \mathrm{~km}$ northwest of the Guangzhou urban center in order to better understand aerosol characteristics of regional air masses and if urban emissions influence regional air quality. Industrial activity in the vicinity of the BG site was relatively low, and the nearest Guang-Qing highway is $\sim 7 \mathrm{~km}$ east of the BG site. However some occasional biomass burning activities in the afternoon and cable burning events in the evening could be potential sources of local emissions (Li et al., 2010; Lu et al., 2010). Specific measurements at the BG site included the study of chemical composition and size distribution (Yue et al., 2010), hygroscopic properties (Rose et al., 2010) and optical properties of aerosol (Garland et al., 2008), various gaseous pollutants (Li et al., 2010; Shao et al., 2011), and oxidants (e.g. hydroxyl radicals, hydrogen peroxide) (Hofzumahaus et al., 2009; Hua et al., 2008; Lou et al., 2010).

\subsection{AMS measurement}

The AMS and other instruments were placed in an airconditioned room on the top floor of a three-story building. Ambient air was introduced from the rooftop to each instrument through a 6-m-long stainless steel tube with an inner diameter of $10 \mathrm{~mm}$. The sample flowrate of the Q-AMS was around $84 \mathrm{cc} \mathrm{min}^{-1}$. A $\mathrm{PM}_{2.5}$ cyclone (URG Corp., USA) was equipped to remove particles larger than $2.5 \mu \mathrm{m}$ in diameter.

The size-resolved chemical compositions of nonrefractory submicron aerosol (i.e., sulfate, ammonium, nitrate, chloride and organics) were measured using a Q-AMS with a time resolution of 10 min during 12-30 July 2006. Details about the instrumentation and performance of QAMS at the BG site can be found in Takegawa et al. (2009) and Xiao et al. (2009). A brief description is provided here. In this study, the inlet temperature, which affects the particle collection efficiency (CE), was controlled at $\sim 40^{\circ} \mathrm{C}$ (about $11^{\circ} \mathrm{C}$ higher than the ambient temperature) to dry the sample air. A CE of 0.5 was assumed under the dry conditions for inorganic and organic compounds (Takegawa et al., 2009). The limit of detection (LOD) for the Q-AMS system is defined as three times the standard deviation of the mass concentration, measured while placing a filter for removing particle in the sample line (Xiao et al., 2009). In this study, the LODs for the Q-AMS were estimated to be $0.10,0.60$, $0.04,0.03$ and $0.40 \mu \mathrm{g} \mathrm{m}^{-3}$ for sulfate, ammonium, nitrate, chloride and organics, respectively (Xiao et al., 2009). The Q-AMS measured the submicron particulate matter $\left(\mathrm{PM}_{1}\right)$ and was not designed to detect refractory components such as mineral dust and EC under typical operating conditions (Takegawa et al., 2005).

\subsection{On-line continuous measurements of WSOC, OC and EC}

Along with the Q-AMS measurements, the concentrations of water soluble organic carbon (WSOC) were measured using a collocated particle-into-liquid-sampler coupled with a total organic carbon analyzer (PILS-TOC) system with a time resolution of $6 \mathrm{~min}$ from 6 to 31 July 2006. The detail of WSOC analysis was described elsewhere (Miyazaki et al., 2009). In brief, to isolate the WSOC into a hydrophilic WSOC ( WSOC $_{\mathrm{hpi}}$ ) and a hydrophobic WSOC (WSOC $\mathrm{Wpo}_{\text {) }}$ component, a macroporous nonionic resin (DAX-8) was used with TOC detection. $\mathrm{WSOC}_{\mathrm{hpo}}$ was defined as the difference between WSOC and $\mathrm{WSOC}_{\text {hpi }}$. The LOD of the WSOC measurement was estimated as $0.1 \mu \mathrm{gC} \mathrm{m}{ }^{-3}$ and the uncertainties in the WSOC and $\mathrm{WSOC}_{\mathrm{hpi}}$ measurements were determined as $9 \%$ and $12 \%$, respectively (Miyazaki et al., 2009). The mass concentrations of EC and OC were measured using a Sunset EC/OC analyzer with a time resolution of $1 \mathrm{~h}$ from 3 to 31 July 2006 (Takegawa et al., 2009a). To estimate artifacts of volatile organic compounds $\left(\mathrm{VOC}_{\mathrm{s}}\right)$ on the quartz filter due to adsorption, a Teflon filter was placed in the sample line to remove particles. The reported OC concentrations were corrected by subtracting the $\mathrm{VOC}_{\mathrm{s}}$ artifact $\left(2.0 \mu \mathrm{gC} \mathrm{m}^{-3}\right)$ from the measured OC concentrations (Takegawa et al., 2009a). A PM 2.5 cyclone was used before 17 July for the measurements of WSOC, OC and EC, but it was changed to a $\mathrm{PM}_{1}$ cyclone after 17 July to be consistent with the Q-AMS measurements.

In addition, the surface meteorological data were obtained with a time resolution similar to other measurements $(10 \mathrm{~min})$ using a portable meteorological station (Vaisala, WXT520) (Xiao et al., 2009).

\subsection{Meteorology}

Meteorological conditions over PRD in July 2006 were characterized by high temperature and much precipitation (Fan et al., 2011). Two high temperature periods occurred from 


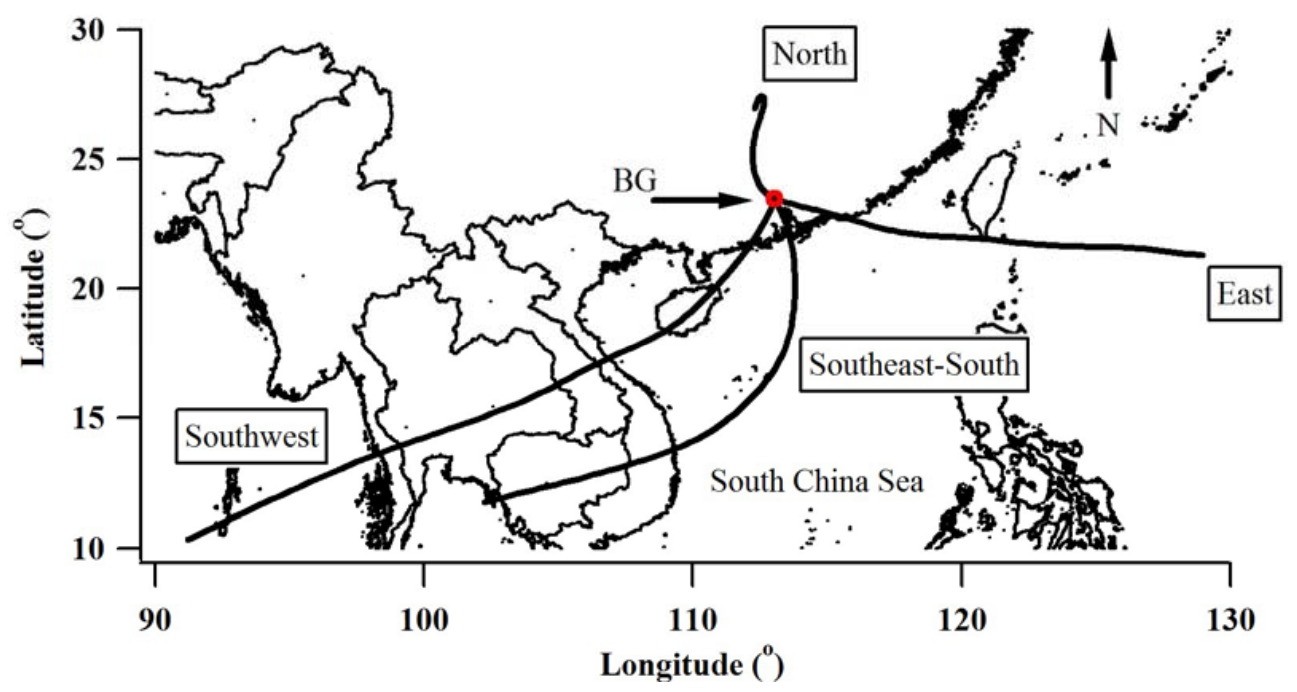

Fig. 1. The 72-h back trajectories of each air mass category calculated using HYSPLIT (http://www.arl.noaa.gov/ready/hysplit4.html).

12-14 July and 20-25 July, respectively. During the campaign, typhoons BILIS and KAEMI landed in the southern China on 14 and 25 July, respectively, leading to heavy rain after the landing of typhoons (Xiao et al., 2009). The air masses can be classified into Southeast-South, Southwest, North and East categories, which account for $41 \%, 13 \%$, $17 \%$ and $14 \%$ of total dataset, according to the observed wind speed (WS) and wind direction (WD). The WS and WD were key meteorological parameters that influence the concentrations of pollutants in the PRD region, especially for the downwind areas (Cheng et al., 2006; Hagler et al., 2006; Lee et al., 2007). Statistical information of the surface meteorological parameters of each category was listed in Table 1. The average 72-h back trajectories were also calculated for each category using the HYSPLIT 4 model (see Fig. 1).

\section{Result and discussion}

\subsection{Characteristics of regional submicron aerosol}

\subsubsection{General characteristics and dynamics}

Figure 2 showed temporal variations of the mass concentrations of sulfate, ammonium, nitrate, chloride, organics and total submicron mass (the sum of these five components) at the BG site. The mass concentrations of sulfate and organics ranged from 1.0 to $52.9 \mu \mathrm{g} \mathrm{m}^{-3}$ and from 1.2 to $152.4 \mu \mathrm{g} \mathrm{m}^{-3}$, respectively. During the sampling period, organics concentrations were normally below $50 \mu \mathrm{g} \mathrm{m}^{-3}$, except for the periods with strong influence by local emission sources (e.g. biomass burning reported by Rose et al., 2010) during 24-25 July. In addition, low concentrations of particulate matter were found between 15 and 17 July and on 27 July due to heavy rains as a result of typhoons. Since this paper mainly focused on the regional air pollution other than local emissions (constituting $\sim 5 \%$ of all data points) or rain events (constituting $\sim 10 \%$ of all data points), these data were excluded in the present analysis. Therefore, the data used in this analysis could represent the general characteristics of air mass in the PRD region. On average, sulfate and organics accounted for $38 \%$ and $44 \%$ of the total submicron mass, corresponding to an average mass concentration of 11.8 and $13.5 \mu \mathrm{g} \mathrm{m}^{-3}$, respectively. Therefore, sulfate and organics dominated submicron aerosol mass, followed by ammonium, nitrate, and chloride, as shown in Table 2 . The total mass concentration in this study was higher than the levels reported by most other field campaigns conducted at various ground sites in urban areas, regions downwind of urban areas, and rural/remote locations in mid-latitude of the Northern Hemisphere (Zhang et al., 2007), indicating that PRD faces serious and challenging particulate air pollution problem (Zhang et al., 2008).

Atmospheric aerosol size distributions are often described as the sum of $n$ lognormal distributions (Seinfeld and Pandis, 2006). The mass size distributions of aerosol species can be fitted to log-normal modes (Salcedo et al., 2006):

$$
\frac{\mathrm{dM}}{d \log D_{\mathrm{va}}}=\sum_{i} \frac{M_{i}}{\sqrt{2 \pi} \log \sigma_{i}} \exp \left[-\frac{\left(\log D_{\mathrm{va}}-\log D_{\mathrm{va}, \mathrm{i}}\right)^{2}}{2 \log ^{2} \sigma_{i}}\right]
$$

Where $M_{i}, D_{\mathrm{va}, i}$, and $\sigma_{i}$ are the mass concentration $\left(\mu \mathrm{g} \mathrm{m}^{-3}\right)$, mean diameter $(\mathrm{nm})$, and geometric standard deviation of the $i$ th lognormal mode, respectively, and log is the base 10 logarithm.

As can be seen in Fig. 3, two lognormal modes can reproduce the observed mass size distributions for both organics and sulfate including the first mode peaking at $D_{\mathrm{va}}$ around $200 \mathrm{~nm}$ and the second mode in the range of $300-700 \mathrm{~nm}$. On average, organics accounted for $56 \%$ of the total mass 
Table 1. Average values of the surface meteorological parameters of each air mass category ${ }^{\mathrm{a}}$.

\begin{tabular}{|c|c|c|c|c|c|}
\hline Type & Pressure $(\mathrm{hPa})$ & Temperature $\left({ }^{\circ} \mathrm{C}\right)$ & $\mathrm{RH}(\%)$ & $\mathrm{WS}\left(\mathrm{m} \mathrm{s}^{-1}\right)$ & $\operatorname{UVA}\left(\mathrm{W} \mathrm{m}^{-2}\right)$ \\
\hline Southeast-South & $1001.1( \pm 1.9)$ & $30.1( \pm 2.5)$ & $73.3( \pm 13.5)$ & $1.6( \pm 0.9)$ & $22.0( \pm 16.7)$ \\
\hline Southwest & $991.3( \pm 3.2)$ & $29.4( \pm 2.9)$ & $74.5( \pm 10.3)$ & $2.2( \pm 1.1)$ & $13.7( \pm 14.1)$ \\
\hline North & $994.6( \pm 2.6)$ & $30.9( \pm 3.3)$ & $70.4( \pm 14.5)$ & $0.9( \pm 0.6)$ & $19.7( \pm 14.9)$ \\
\hline East & $999.0( \pm 2.3)$ & $26.4( \pm 1.5)$ & $81.9( \pm 7.1)$ & $2.3( \pm 0.9)$ & $21.5( \pm 16.6)$ \\
\hline
\end{tabular}

a Numbers in parentheses are one standard deviations.

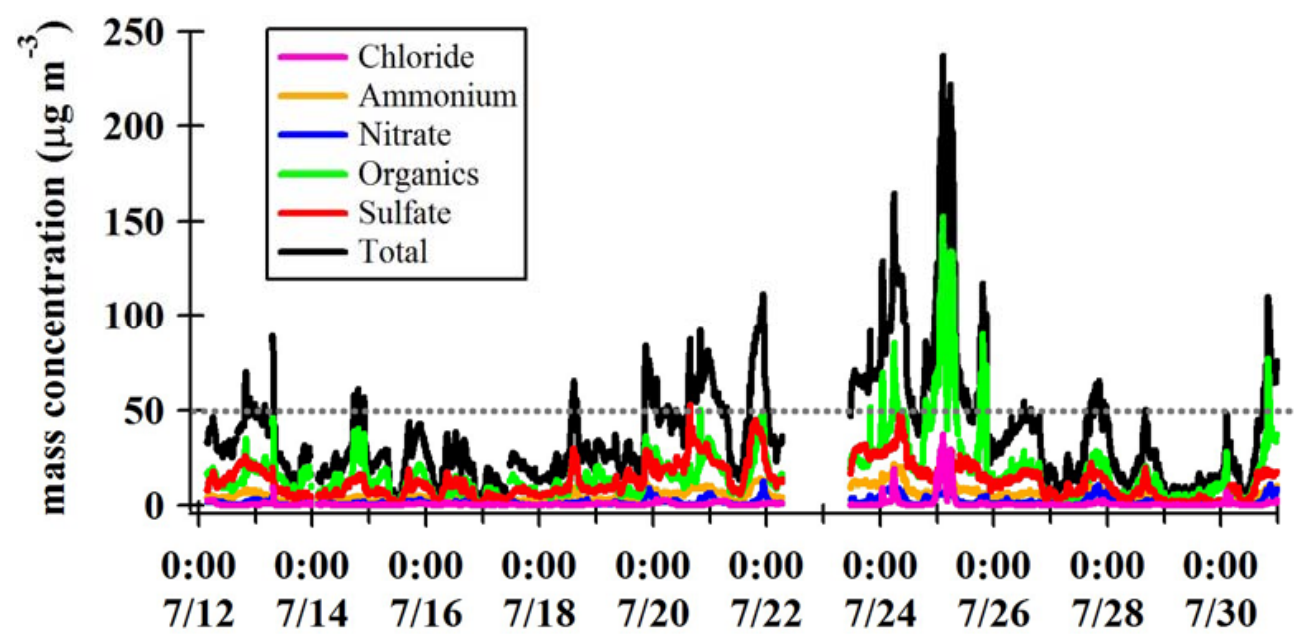

Fig. 2. Time series of the mass concentrations of sulfate, ammonium, nitrate, chloride, organics and total (the sum of these five components).

of submicron particles in the first mode, but its percentage decreased to $39 \%$ in the second mode. On the contrary, the percentage of sulfate increased from $31 \%$ in the first mode to $35 \%$ in the second mode.

The PRD region is located in pollution control zones of acid rain and sulfur dioxide, which were designated by the Ministry of Environmental Protection of the People's Republic of China. Therefore, the study of apparent acidity in this region is very important. Based on the AMS measurements, apparent acidity was assessed by comparing measured $\mathrm{NH}_{4}^{+}\left(=\mathrm{NH}_{4}^{+} / 18 \mu \mathrm{eq} \mathrm{m}{ }^{-3}\right)$ to the amount needed to fully neutralize the measured anions $\mathrm{SO}_{4}^{2-}, \mathrm{NO}_{3}^{-}$and $\mathrm{Cl}^{-}$ (i.e. predicted $\mathrm{NH}_{4}^{+}=2 * \mathrm{SO}_{4}^{2-} / 96+\mathrm{NO}_{3}^{-} / 62+\mathrm{Cl}^{-} / 35.5 \mu \mathrm{eq}$ $\mathrm{m}^{-3}$ ), as shown in Fig. 4. The slope of measured versus predicted $\mathrm{NH}_{4}^{+}$was $0.81\left(r^{2}=0.95\right)$. In addition, apparent acidity was also estimated based on the comparison of measured cation to the predicted cation with the data from filter measurements (i.e. measured cation $=\mathrm{NH}_{4}^{+} / 18+\mathrm{Na}^{+} / 23$ $+\mathrm{K}^{+} / 39+2 \mathrm{Mg}^{2+} / 24+\mathrm{Ca}^{2+} / 40, \mu$ eq $\mathrm{m}^{-3}$ and predicted cation $=2 \mathrm{SO}_{4}^{2-} / 96+\mathrm{NO}_{3}^{-} / 62+\mathrm{Cl}^{-} / 35.5+\mathrm{F}^{-} / 19 \mu \mathrm{eq} \mathrm{m}^{-3}$ ). The slope of measured versus predicted cation was 0.77 $\left(r^{2}=0.98\right)$. Both analyses revealed that particles in the PRD regional air mass are acidic. The comparison between acidity estimate by AMS and filter-based data suggested that
AMS inorganic species can be effectively used to assess the acidity of submicron particles because these finer particles generally contain very low concentrations of $\mathrm{Na}^{+}, \mathrm{K}^{+}$, $\mathrm{Mg}^{2+}, \mathrm{Ca}^{2+}$ and $\mathrm{F}^{-}$ions, which is consistent with the results by Liu X. G. et al. (2008). As a result of fuel supply shortage, large amounts of high-sulfur coal and highsulfur fuel oil are still in use by many companies in PRD (http://www.gzepb.gov.cn), which are mainly responsible for acidity of aerosol in this region.

Diurnal patterns of sulfate, ammonium, nitrate, chloride and organics are presented in Fig. 5. The mass concentrations of sulfate showed a pronounced diurnal variation, which almost doubled from 10:00 to 17:00 local time (LT, Beijing time) with an average increasing rate of $\sim 1.0 \mu \mathrm{g} \mathrm{m}^{-3} \mathrm{~h}^{-1}$. The increase appeared to be driven by the enhanced photochemical reactions during the day. The average concentrations of ammonium also increased during the day, probably as a result of neutralization of the sulfate. However, the daytime increase was not obvious for organics, but it quickly reached a maximum concentration of as high as $\sim 20 \mu \mathrm{g} \mathrm{m}^{-3}$ between 17:00-20:00 LT. The observed variations of organics might be attributed to combined effects of enhanced vehicular emissions during traffic hours and lower mixing layer height that traps the PRD urban primary emissions and some photochemically formed secondary products. 
Table 2. Average concentrations (unit: $\mu \mathrm{g} \mathrm{m}^{-3}$ ) of submicron aerosol species of each air mass category ${ }^{\mathrm{a}}$.

\begin{tabular}{lrrrrrr}
\hline Type & ammonium & nitrate & sulfate & chloride & organics & Total $^{\text {b }}$ \\
\hline Southeast-South & $4.1( \pm 2.7)$ & $1.3( \pm 1.4)$ & $13.4( \pm 8.6)$ & $0.5( \pm 0.6)$ & $12.8( \pm 7.8)$ & $32.0( \pm 19.1)$ \\
Southwest & $3.3( \pm 1.5)$ & $1.0( \pm 0.5)$ & $10.1( \pm 3.8)$ & $0.2( \pm 0.2)$ & $15.7( \pm 6.3)$ & $30.3( \pm 10.9)$ \\
North & $5.2( \pm 3.9)$ & $1.8( \pm 2.0)$ & $14.8( \pm 9.6)$ & $0.5( \pm 1.0)$ & $18.7( \pm 10.9)$ & $40.9( \pm 25.8)$ \\
East & $2.0( \pm 1.8)$ & $1.4( \pm 1.8)$ & $4.7( \pm 3.7)$ & $0.3( \pm 0.5)$ & $7.3( \pm 5.3)$ & $15.9( \pm 12.6)$ \\
\hline
\end{tabular}

${ }^{a}$ Numbers in parentheses are one standard deviations. ${ }^{b}$ Total (the sum of these five components).
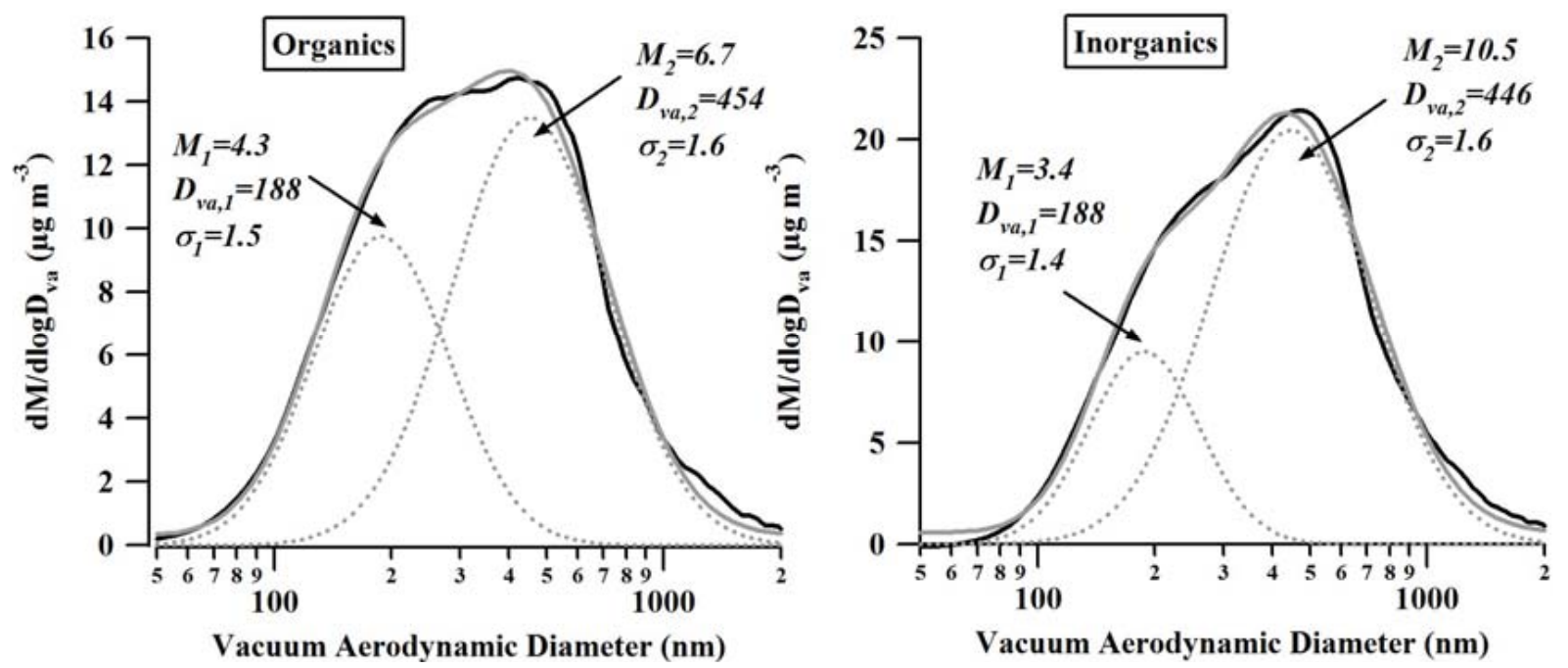

Fig. 3. Fitting two log-normal modes to the average size distributions of organics and inorganics (the sum of four inorganic species). The black (grey) line indicates the measured (fitted) concentrations.

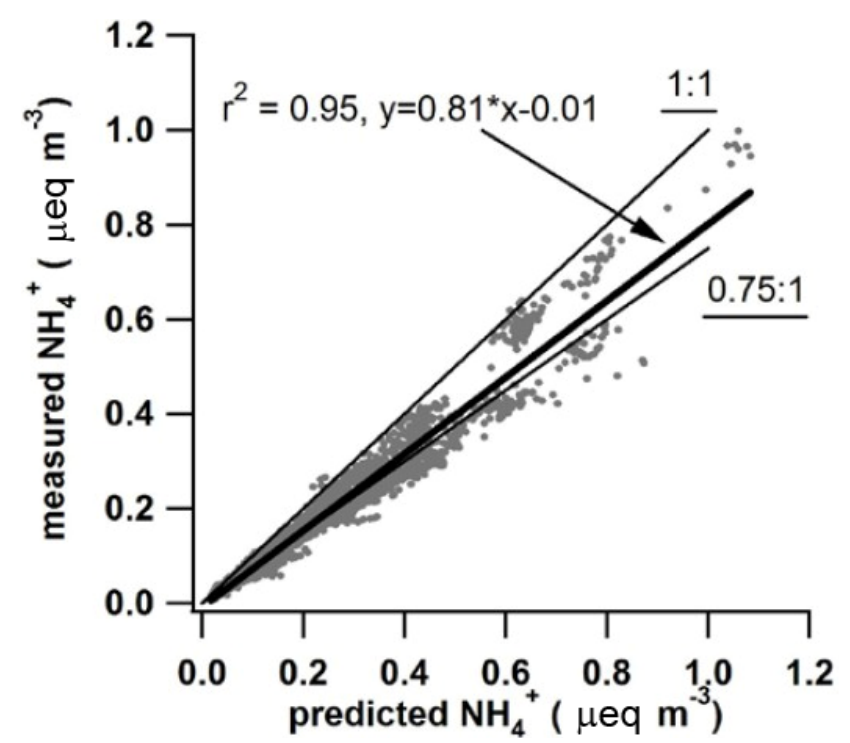

Fig. 4. Scatter plot of measured $\mathrm{NH}_{4}^{+}\left(=\mathrm{NH}_{4}^{+} / 18 \mu \mathrm{eq} \mathrm{m}^{-3}\right)$ versus predicted $\mathrm{NH}_{4}^{+}\left(=2 \mathrm{SO}_{4}^{2-} / 96+\mathrm{NO}_{3}^{-} / 62+\mathrm{Cl}^{-} / 35.5 \mu \mathrm{eq} \mathrm{m}{ }^{-3}\right)$.
The mass concentrations of nitrate and chloride also showed a pronounced diurnal profile that peaks in the early morning or during nighttime, but stay low between 10:00-17:00 LT. This profile was likely due to the gas-to-particle partitioning of ammonium nitrate and ammonium chloride precursors, which favor particulate phase at lower temperature and high relative humidity conditions (Seinfeld and Pandis, 2006).

\subsubsection{Aerosol characteristics associated with different air masses}

As shown in Fig. 1, four categories of air masses reaching the BG site during the study period were identified. Statistics of the mass concentrations of AMS species in each air mass category were listed in Table 2.

For each air mass category, the average size distribution for organics, sulfate, nitrate, ammonium, and chloride was shown in Fig. 6 and the ion balances of different air masses in Fig. 7. For the Southeast-South air mass category, the submicron aerosol particles displayed distinct bimodal size distributions and were acidic (slope of measured $\mathrm{NH}_{4}^{+}$versus predicted $\left.\mathrm{NH}_{4}^{+}=0.68 ; r^{2}=0.99\right)$. A slope of 0.75 suggested that roughly $50 \%$ of sulfate $\left(\mathrm{SO}_{4}^{2-}\right)$ molecules in the 


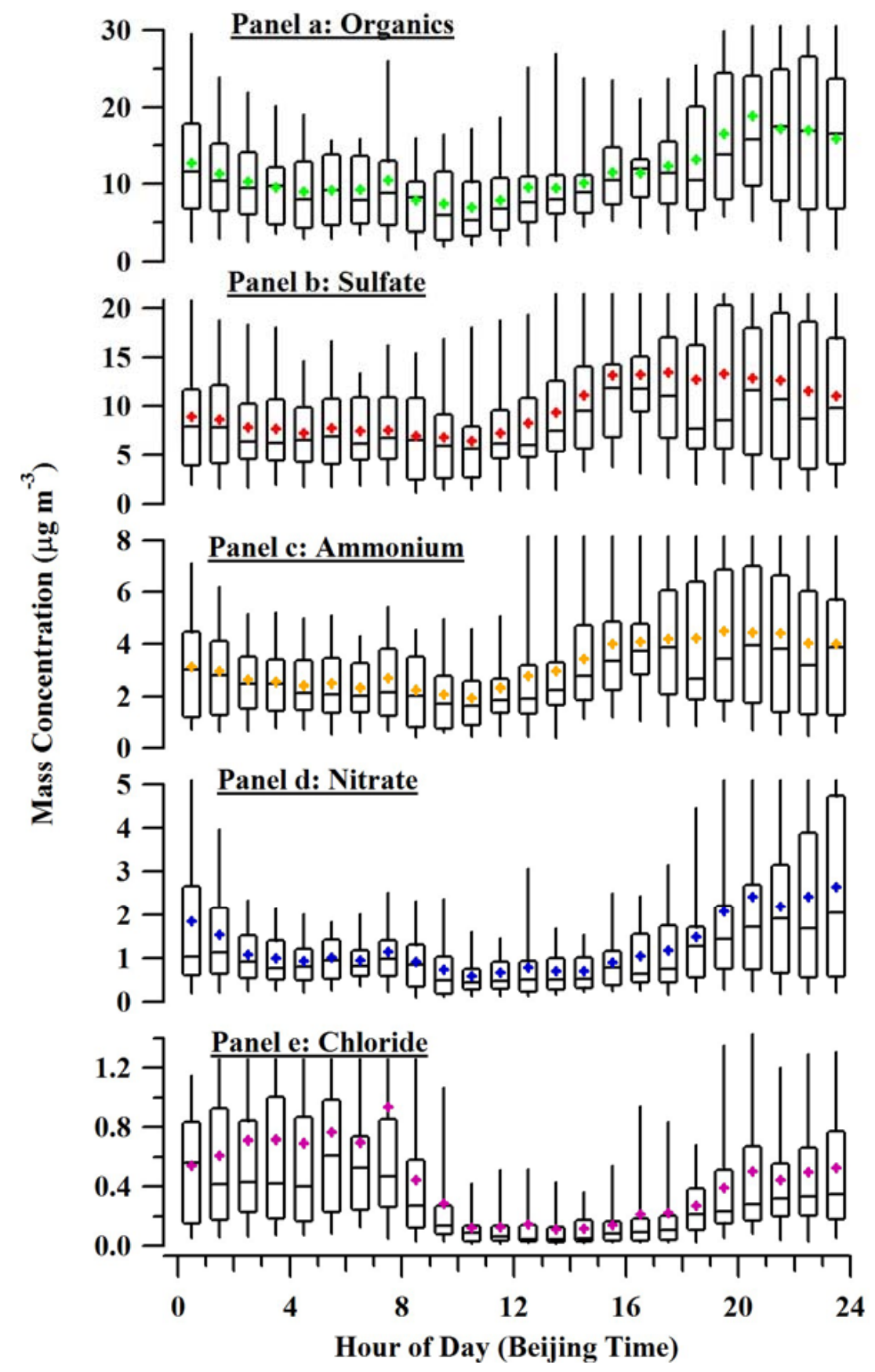

Fig. 5. Diurnal variation box plots of Panel (a): organics, Panel (b): sulfate, Panel (c): ammonium, Panel (d): nitrate and Panel (e): chloride. The box plots are read as follows: the upper and lower boundaries of the box indicate the 75th and the 25th percentiles, the line within the box marks the median, and the whiskers above and below the box indicate the 95th and 5th percentiles. Cross symbols represent the means.

aerosol particles are in the form of bisulfate $\left(\mathrm{HSO}_{4}^{-}\right)$( $\mathrm{Zhang}$ et al., 2005c). These air masses passed PRD urban areas before reaching the rural BG site. In contrast, for the North and Southwest categories, the size distributions for organics and sulfate generally showed unimodal characteristics and the mean peak diameter moved to larger size range, indicating more aged particles. These aerosol particles were bulk neutralized (slope $=0.93-0.95$, close to $\left.1 ; r^{2}=0.93-0.98\right)$. For the air masses from the Eastern areas, organics showed bimodal size distributions though it was not that obvious for inorganic species and particles were bulk neutralized in this category (slope $=0.91$, close to $1 ; r^{2}=0.99$ ).

To further understand chemical compositions of organic aerosol in each mode, the AMS spectral data were examined. 

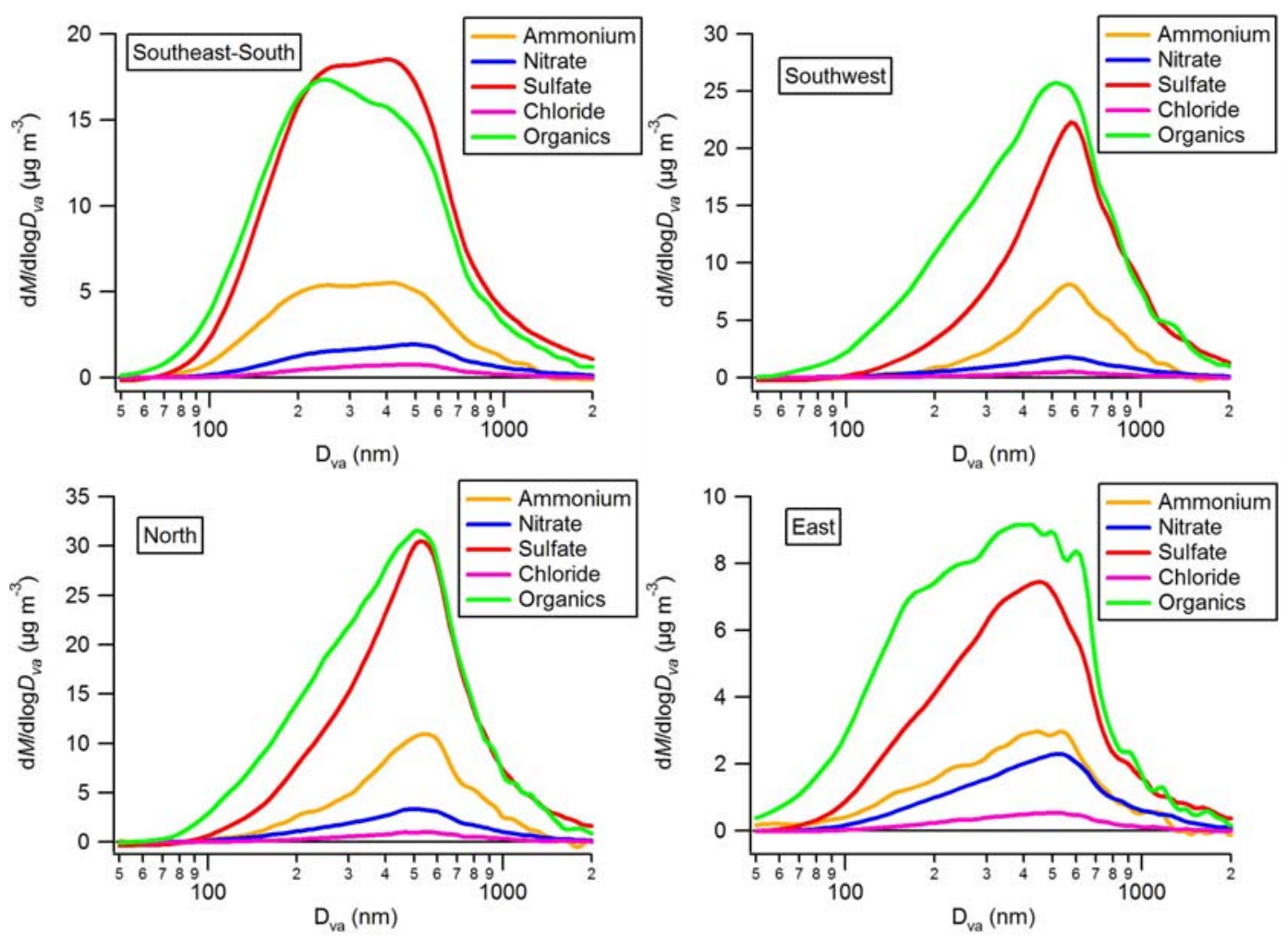

Fig. 6. Average size distributions of submicron aerosol species of each air mass category.

The size distributions of organic mass fragment $\mathrm{m} / \mathrm{z}, 44$ $\left(\mathrm{CO}_{2}^{+}\right)$and $m / z, 57\left(\mathrm{C}_{4} \mathrm{H}_{9}^{+}\right)$for the Southeast-South category were illustrated in Figure 8. Fragment $\mathrm{m} / \mathrm{z} 44$ was a representative tracer of oxygenated organic aerosol, while fragment $m / z 57$ was typically associated with combustion exhaust (Alfarra et al., 2004). The $m / z 44$ mass size distributions often exhibited pronounced unimodal characteristics at rural and urban sites, with its $D_{\text {va }}$ ranging from 300 to $700 \mathrm{~nm}$, suggesting oxygenated organic aerosol dominated the second mode (Kondo et al., 2007). However, at the BG site, it was found that the size distribution of $m / z, 44$ was bimodal, indicating significant contribution from oxygenated organic aerosol to total OA in the first mode (Fig. 6). It is not surprising to find that the size distribution of $\mathrm{m} / \mathrm{z} 57$ was dominated by the first mode since it is primarily from combustion-related emissions. The present of $\mathrm{m} / z 57$ in the large mode may indicate that the air mass we sampled was relatively aged comparing to the fresh emissions, since the contributions of $\mathrm{m} / \mathrm{z} 57$ in the small-mode particles tend to decrease in aged air (Alfarra et al., 2004). Previous studies have shown that organics often exhibited bimodal size distributions at urban sites (Alfarra et al., 2004, 2007; Allan et al., 2003a, b, 2004; Jimenez et al., 2003; Kondo et al., 2007; Salcedo et al., 2006; Sun et al., 2010; Zhang et al., 2005c) with the first organic mode attributed to combustion-related emissions (e.g. traffic) and the second organic mode contributed by photochemical processing (Alfarra et al., 2004, 2007). However, the $m / z, 44$ and $m / z 57$ size distributions from AMS data revealed that the first mode of organics in the SoutheastSouth air mass category was contributed by both primary emissions and secondary organic aerosol formations. The first mode of $m / z, 44$ represents species from secondary formation, namely the gas-phase oxidation of volatile organic compound precursors (Xiao et al., 2009).

At the BG site, the mass concentrations of sulfate showed bimodal size distributions for the Southeast-South category. Nevertheless, the bimodal size distributions of sulfate have not been found in most urban areas such as Tokyo (Miyakawa et al., 2008) and New York (Weimer et al., 2006), as well as rural/remote sites such as Fukue Island in Japan and Jeju Island in Korea (Takami et al., 2005; Topping et al., 2004). In this study, the first mode of sulfate was attributed to homogeneous gas-phase reactions of $\mathrm{SO}_{2}$ initiated by the reaction with the $\mathrm{OH}$ radical, and the average sulfate production rate was $\sim 1.04 \mu \mathrm{g} \mathrm{m}^{-3} \mathrm{~h}^{-1}\left(\sim 0.26 \mathrm{ppbv} \mathrm{h}^{-1}\right)$ in a typical air mass transported from the southeast PRD areas. This rate was comparable to the average increasing rate of $\sim 1.00 \mu \mathrm{g} \mathrm{m}^{-3} \mathrm{~h}^{-1}$ during the day (see Sect. 3.1.1). This implied that the gas-phase oxidation of $\mathrm{SO}_{2}$, due to the high concentrations of $\mathrm{SO}_{2}$ and $\mathrm{OH}$ (Hofzumahaus et al., 2009), was important to the increase of sulfate during the day in the PRD region. The second mode usually was attributed to 

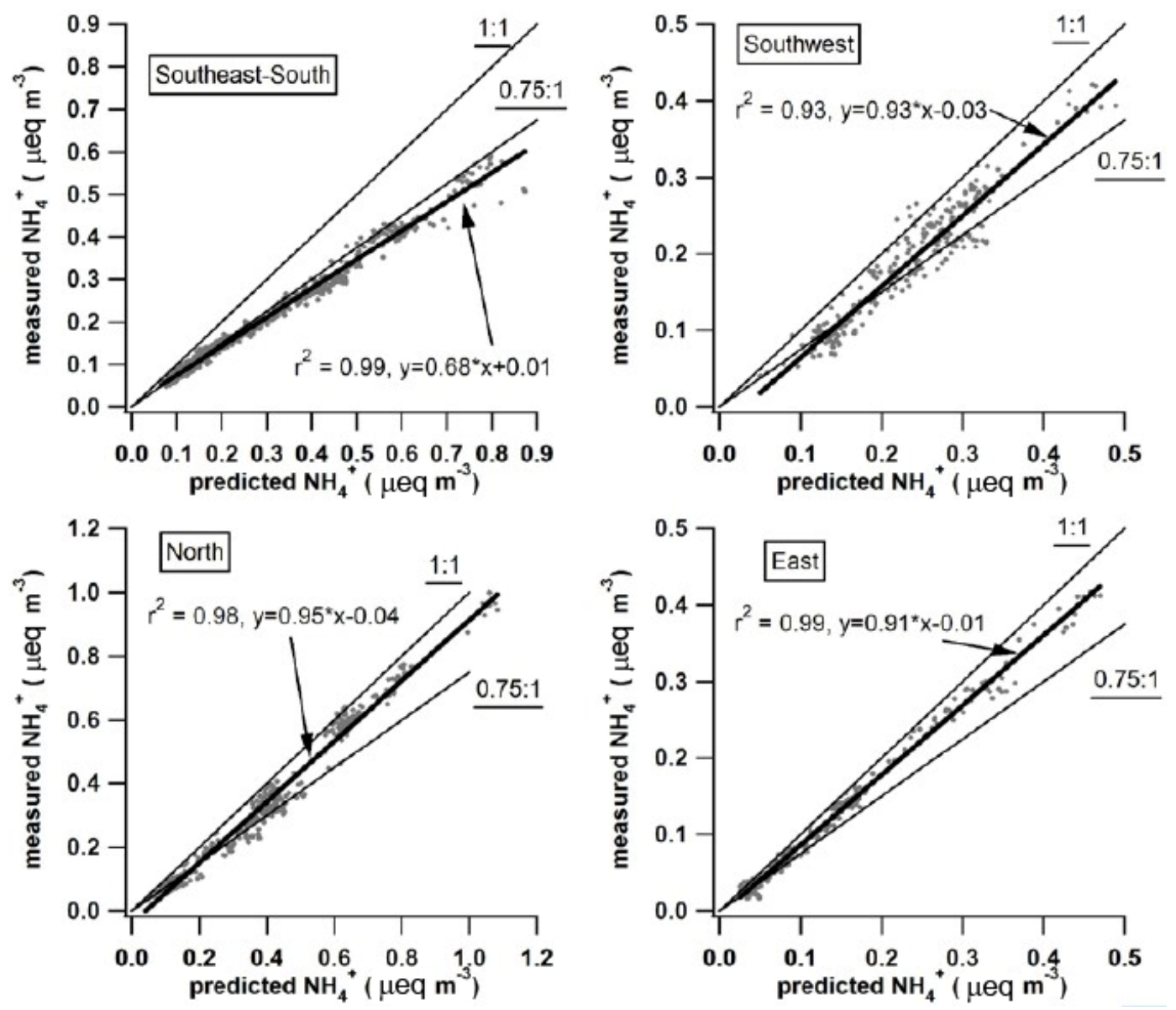

Fig. 7. Scatter plots of measured $\mathrm{NH}_{4}^{+}\left(=\mathrm{NH}_{4}^{+} / 18 \mu\right.$ eq $\left.\mathrm{m}^{-3}\right)$ versus predicted $\mathrm{NH}_{4}^{+}\left(=2 \mathrm{SO}_{4}^{2-} / 96+\mathrm{NO}_{3}^{-} / 62+\mathrm{Cl}^{-} / 35.5 \mu\right.$ eq m$\left.{ }^{-3}\right)$ for each air mass category. The black lines represent the regression lines. The grey lines indicate 1:1 reference lines. The blue lines indicate 0.75:1 reference lines.

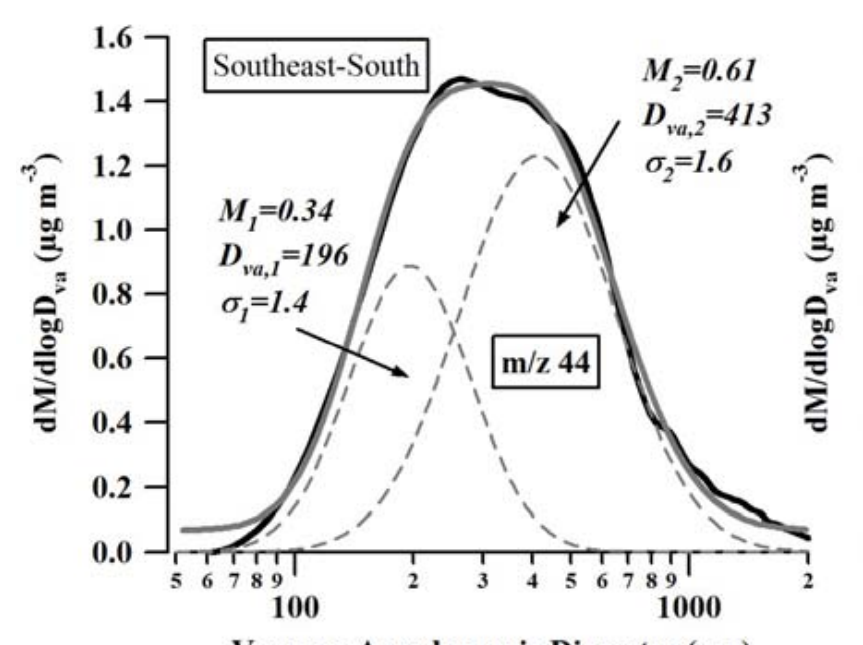

Vacuum Aerodynamic Diameter (nm)

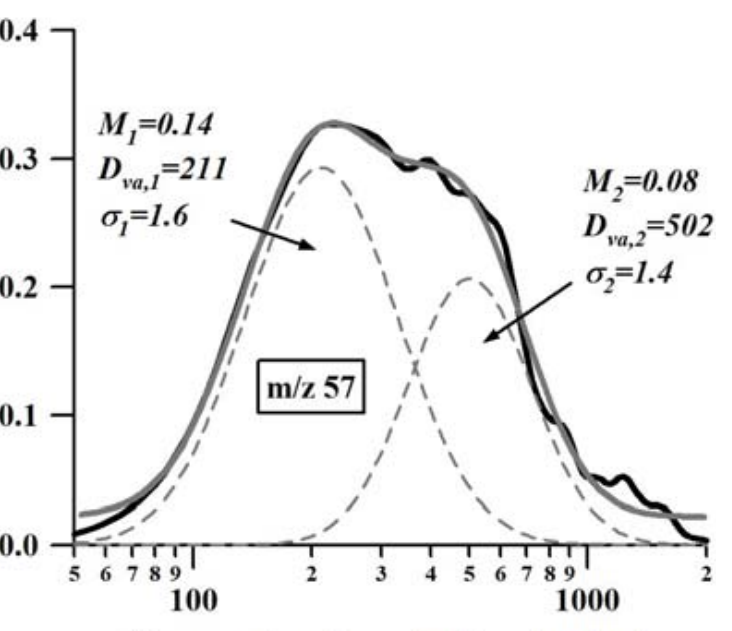

Vacuum Aerodynamic Diameter (nm)

Fig. 8. Fitting two log-normal modes to the average size distributions of $m / z$, 44 and $m / z 57$ of Southeast-South category. The black (grey) line indicates the measured (fitted) concentrations. 


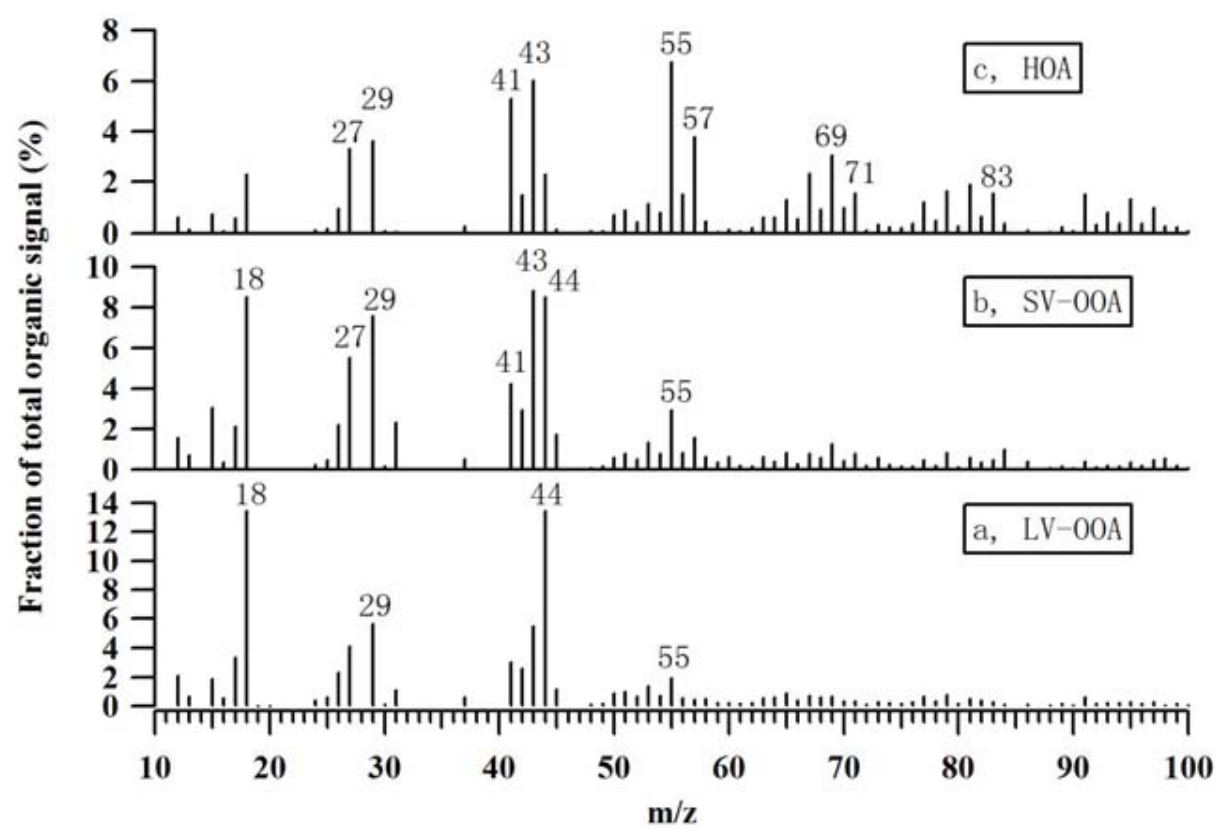

Fig. 9. Mass spectra of the three organic components identified by PMF.
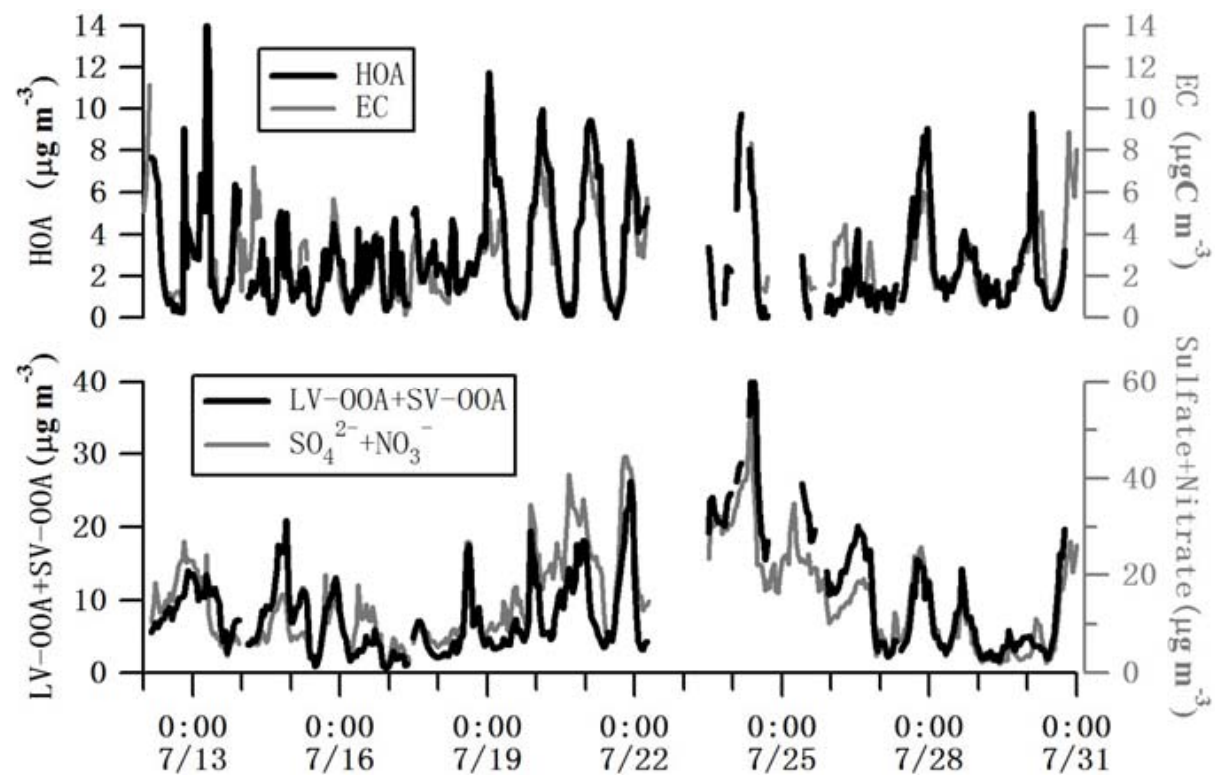

Fig. 10. Time series of HOA and primary aerosol species EC, of LV-OOA+SV-OOA and secondary aerosol species Sulfate+Nitrate.

in-cloud processing (Meng and Seinfeld, 1994; Yao et al., 2002, 2003a, b).

\subsection{Sources of organic aerosol}

\subsubsection{Source apportionment by PMF}

PMF (Paatero and Tapper, 1994; Paatero, 1997) is the most widely used method to deconvolve AMS organic data. The principle and application of PMF method to AMS data have been described in detail elsewhere (Lanz et al., 2007; Ulbrich et al., 2009). A reference mass spectral database has been established by Ulbrich et al. (2007). Sources are identified based on the similarities to reference mass spectra of known sources and correlations between PMF components and commonly used tracers such as EC for primary combustion sources (Lanz et al., 2007; Ulbrich et al., 2009).

Three factors or components of organic aerosol were identified by the PMF model at the BG site (see Fig. 9). Spectral 


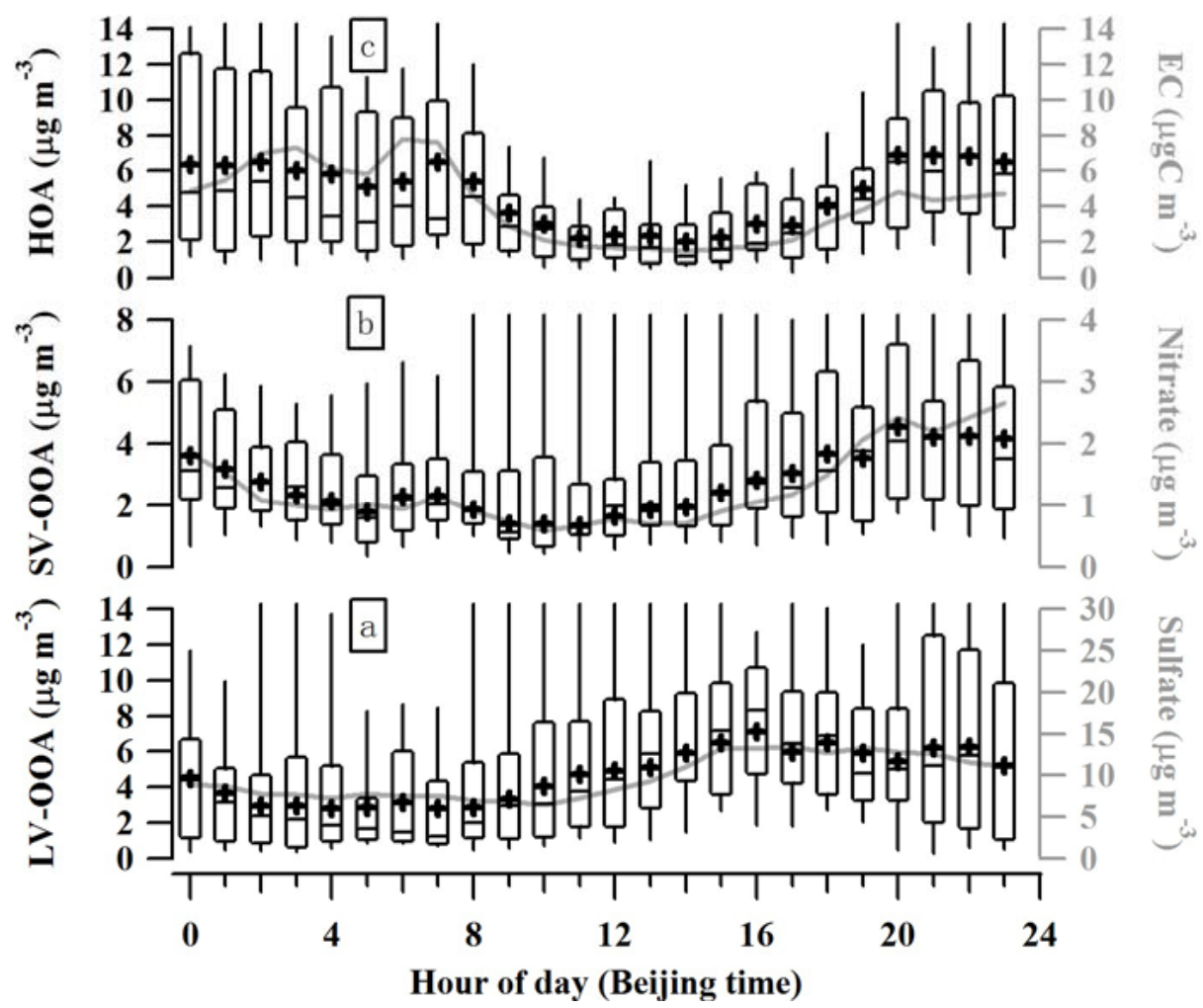

Fig. 11. Diurnal variation box plots of HOA, SV-OOA and LV-OOA. The box plots are read as follows: the upper and lower boundaries of the box indicate the 75th and the 25th percentiles, the line within the box marks the median, and the whiskers above and below the box indicate the 95 th and 5th percentiles. Cross symbols represent the means. The grey lines indicate the diurnal variations of EC, Nitrate and Sulfate, respectively.
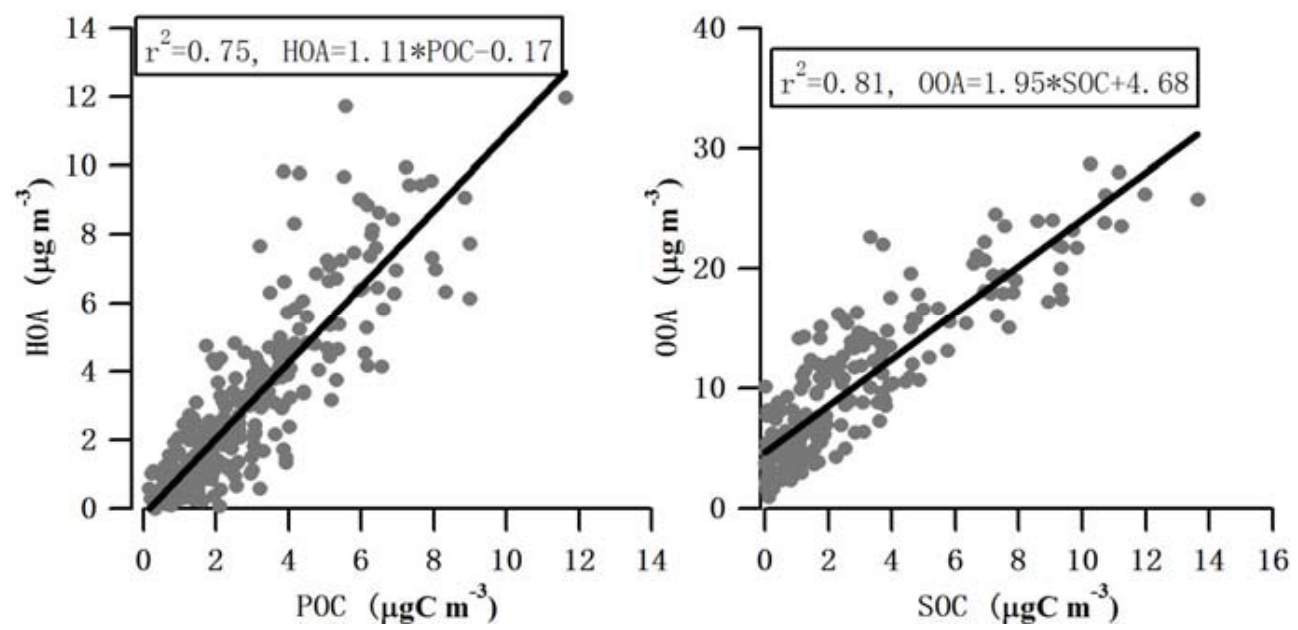

Fig. 12. Scatter plots of HOA vs. POC and OOA vs. SOC.

similarity, which is determined by the $r^{2}$ of two organic mass spectra, is commonly used to provide insight into the organic sources in previous publications (Lanz et al., 2007, 2008; Sun et al., 2010; Zhang et al., 2005a, b). In this study, the mass spectra of the three organic components in Fig. 9 were correlated with the reference mass spectra of the database. The mass spectrum of HOA was strongly correlated with those of primary organic aerosol particles from Pittsburgh (Zhang et al., 2005a, b; Ulbrich et al., 2009), Vancouver (Alfarra et al., 2004), Zurich (Lanz et al., 2007; 2008) and 
Table 3. Correlation matrix of HOA, SV-OOA, LV-OOA, and primary and secondary aerosol tracers ${ }^{\mathrm{a}}$.

\begin{tabular}{|c|c|c|c|c|c|c|c|c|c|}
\hline & LV-OOA & SV-OOA & $\mathrm{HOA}$ & Sulfate & Nitrate & $\mathrm{EC}$ & Sulfate+Nitrate & $\mathrm{OOA}^{\mathrm{b}}$ & WSOC \\
\hline LV-OOA & 1 & 0.28 & 0.09 & 0.75 & 0.46 & 0.26 & 0.77 & 0.92 & 0.82 \\
\hline SV-OOA & & 1 & 0.21 & 0.45 & 0.67 & 0.41 & 0.65 & 0.64 & 0.67 \\
\hline $\mathrm{HOA}$ & & & 1 & 0.26 & 0.49 & 0.86 & 0.33 & 0.16 & 0.47 \\
\hline Sulfate & & & & 1 & 0.52 & 0.40 & 0.99 & 0.79 & 0.64 \\
\hline Nitrate & & & & & 1 & 0.48 & 0.64 & 0.68 & 0.73 \\
\hline $\mathrm{EC}$ & & & & & & 1 & 0.39 & 0.27 & 0.45 \\
\hline Sulfate + Nitrate & & & & & & & 1 & 0.80 & 0.70 \\
\hline OOA & & & & & & & & $\mathbf{1}$ & 0.84 \\
\hline WSOC & & & & & & & & & 1 \\
\hline
\end{tabular}

${ }^{\mathrm{a}}$ Correlation is significant at the 0.01 level. ${ }^{\mathrm{b}} \mathrm{OOA}=\mathrm{LV}-\mathrm{OOA}+\mathrm{SV}-\mathrm{OOA}$.

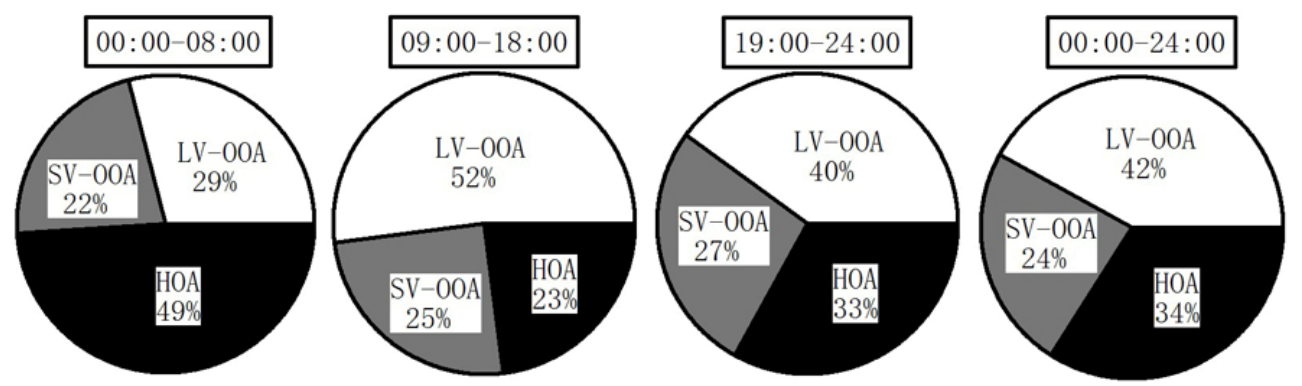

Fig. 13. Relative contributions of HOA and OOA during different hours of the day.

Manchester (Allan et al., 2003a, b, 2004) ( $r^{2}$ in the range of 0.91-0.96), as well as reference spectra of diesel and gasoline engine exhaust ( $r^{2}$ ranging from 0.91 to 0.95 ). The mass spectrum of HOA was dominated by organic fragments for saturated hydrocarbons $\mathrm{C}_{\mathrm{n}} \mathrm{H}_{2 \mathrm{n}+1}^{+}(\mathrm{m} / z, 29,43,57,71)$ and unsaturated hydrocarbons $\mathrm{C}_{\mathrm{n}} \mathrm{H}_{2 \mathrm{n}-1}^{+}(\mathrm{m} / z 27,41,55,69,83)$. The mass spectrum of low volatility OOA (LV-OOA) was most comparable with those of secondary organic aerosol particles from Pittsburgh (Zhang et al., 2005a, b; Ulbrich et al., 2009), Zurich (Lanz et al., 2007, 2008) and Langley (Alfarra et al., 2004) ( $r^{2}$ from 0.93-0.99), but also highly correlated with reference spectra of fulvic acid (representing aged and oxygenated aerosol, $r^{2}$ as 0.93 ). The LV-OOA demonstrated a quite different fragmentation pattern from HOA and exhibited characteristic fragments of oxidized organic aerosol such as $m / z 44$ and $m / z$ 18. The mass spectrum of semi-volatile OOA (SV-OOA) had the highest correlation with the semi-volatile OOA $\left(r^{2}=0.88\right)$ reported in Pittsburgh (Ulbrich et al., 2009). SV-OOA differed from LVOOA in that it contained fragments from both hydrocarbon compounds and oxygenated species. Atmospheric SV-OOA represents fresh secondary organic aerosol that eventually evolves into LV-OOA with continued photochemical processing (Jimenez et al., 2009). Thus, the highest abundance of $m / z 44$ was found in LV-OOA (13.5\% in total $m / z 44$ signal), followed by SV-OOA (8.5\%) and HOA (2.3\%), which suggests that SV-OOA is less oxygenated than LV-OOA but more oxygenated than HOA.

The time series of HOA and OOA (LV-OOA plus SVOOA) together with primary and secondary aerosol tracers was presented in Fig. 10. The mass concentration of HOA correlated well with that of EC, a typical tracer of combustion emissions ( $r^{2}$ as 0.75 ). HOA exhibited a clear diurnal variation that peaked at traffic hours (early morning and late afternoon) and stayed at low levels during the day (see Fig. 11). The emission ratio of HOA versus EC is calculated from the slope $b$ of linear regression model: $\mathrm{HOA}=a+b \mathrm{EC}$ (Lanz et al., 2007). In this study, the emission ratio of HOA to EC was $1.2 \mu \mathrm{g} \mu \mathrm{gC}^{-1}$, similar to values reported in Pittsburgh $\left(1.41 \mu \mathrm{g} \mu \mathrm{gC}^{-1}\right)$ by Zhang et al. (2005a, b) and in Zurich $\left(1.1 \mu \mathrm{g} \mu \mathrm{gC}^{-1}\right)$ by Lanz et al. (2007), as well as $1.2 \mu \mathrm{g} \mu \mathrm{gC}^{-1}$ estimated from emission inventory by Cabada et al. (2002). These results suggested that the sampling site was significantly influenced by upwind combustion emissions of city plume. Tight correlation of OOA with the sum of sulfate and nitrate was also found $\left(r^{2}\right.$ as 0.65$)$, and the slope of 0.57 was similar to that reported in Beijing $(0.42)$ by Sun et al. (2010). A strong correlation between LV-OOA and nonvolatile sulfate and between SV-OOA and semi-volatile nitrate was shown in Fig. 11 and Table 3, which is consistent with findings from previous studies (Jimenez et al., 2009; Lanz et al., 2007). LV-OOA is more aged OA while SV-OOA 


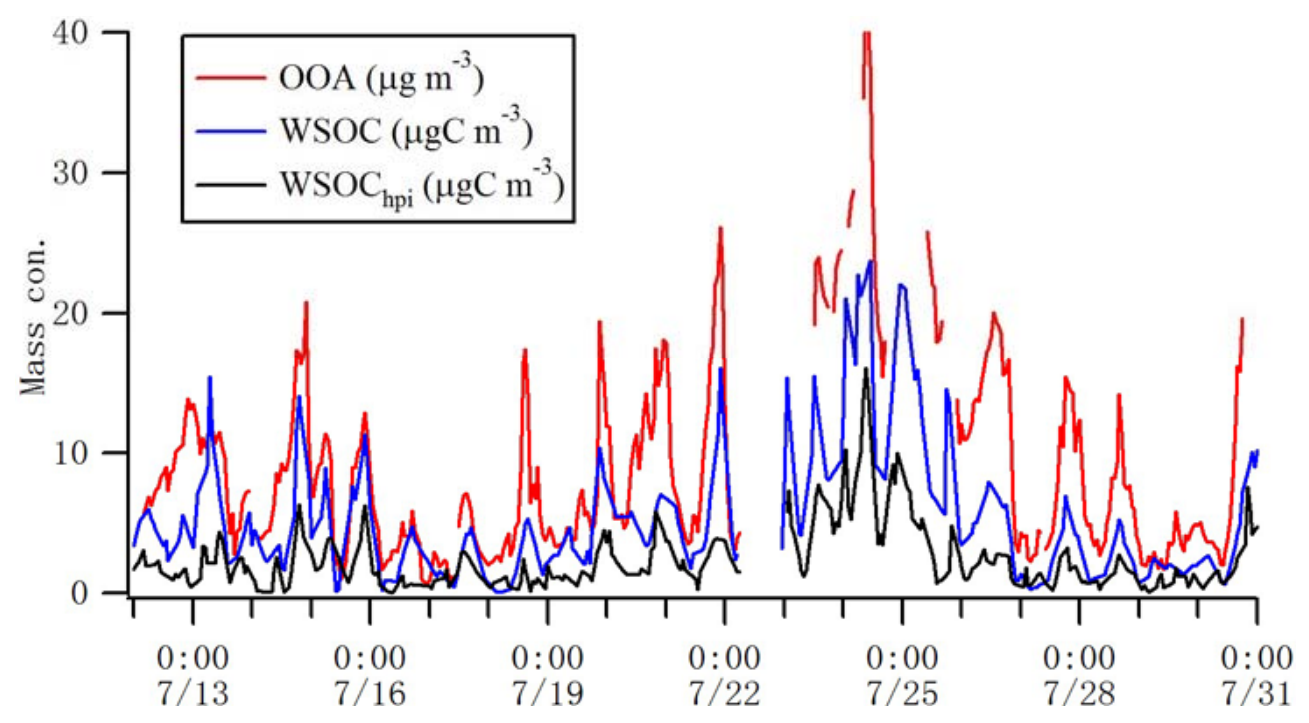

Fig. 14. Time series of OOA, WSOC and $\mathrm{WSOC}_{\mathrm{hpi}}$.

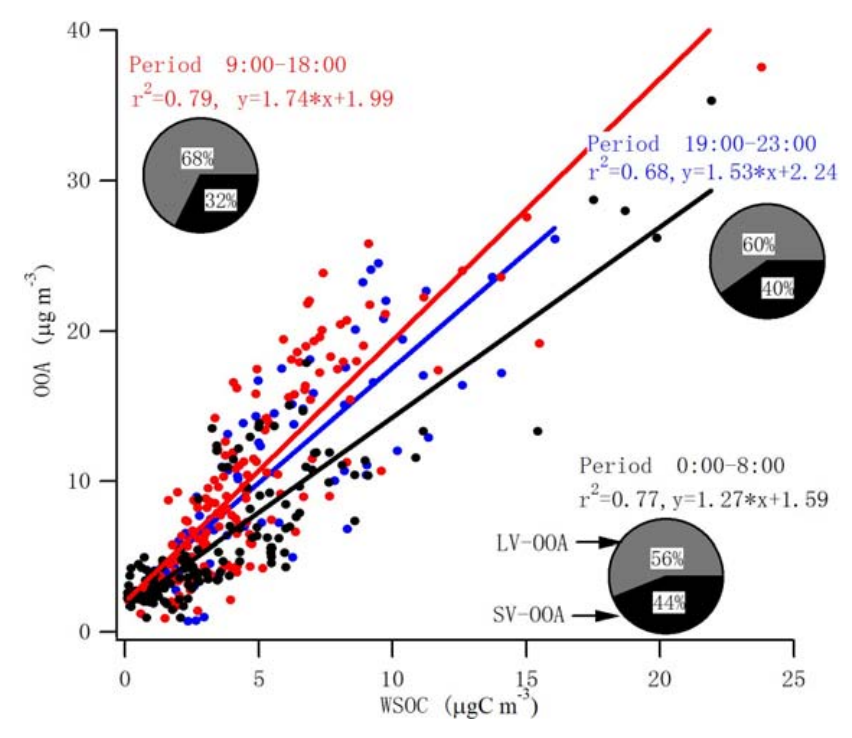

Fig. 15. Scatter plots of OOA vs. WSOC during different hours of the day. The pie charts indicate the relative contributions of the two subtypes of OOA (i.e. LV-OOA \& SV-OOA) to OOA.

is likely less-photochemically aged OA, but the relative contributions of the two OOA subtypes depend on both ambient temperature and the extent of photochemical transformation (Jimenez et al., 2009). The mass concentration of LVOOA showed a pronounced diurnal variation that increased from $4.0 \mu \mathrm{g} \mathrm{m}^{-3}$ at 10:00 LT to $7.1 \mu \mathrm{g} \mathrm{m}^{-3}$ at 16:00 LT, with an average increasing rate of $0.5 \mu \mathrm{g} \mathrm{m}^{-3} \mathrm{~h}^{-1}$. LV-OOA is closely linked to photochemistry. The mass concentration of SV-OOA reached the highest level between 20:00-24:00 LT, probably due to a shift in the gas-particle equilibrium of semi-volatile secondary organic aerosol after sunset.
In summary, total OOA constituted about $66 \%$ of submicron OA mass during the total sampling period, in which LV-OOA and SV-OOA accounted for $38 \%$ and $28 \%$ of OA mass, respectively.

\subsubsection{Comparison between results from PMF and the EC tracer method}

The EC tracer method is frequently used to estimate the amount of secondary organic carbon based on the assumption that EC can be used as a tracer for primary combustiongenerated OC, thus excess OC is from secondary organic aerosol formation process (Cabada et al., 2004; Dechapanya et al., 2004; Turpin and Huntzicker, 1995). In this study, the mass concentrations of primary organic carbon (POC) and secondary organic carbon (SOC) were estimated with the following equations: $\mathrm{POC}=1.1 \times \mathrm{EC}$ and $\mathrm{SOC}=\mathrm{OC}-\mathrm{POC}$. The estimated POC/EC ratio was similar to the values of 1.11.3 for $\mathrm{PM}_{2.5}$ in the PRD region in previous studies (Cao et al., 2003, 2004).

Positive correlations between $\mathrm{HOA}$ and POC $\left(r^{2}=\right.$ $0.75)$ and between OOA and SOC $\left(r^{2}=0.81\right)$ were found (Fig. 12). The slope of HOA versus POC was $1.11 \mu \mathrm{g} \mu \mathrm{gC}^{-1}$, similar to the HOA/HOC (hydrocarbon-like organic carbon equals to total carbon of $\mathrm{HOA}$ ) ratios in Tokyo (1.2 $\mu \mathrm{g} \mathrm{ge}^{-1}$, Kondo et al., 2007) and in Pittsburgh $\left(1.2 \mu \mathrm{g} \mu \mathrm{gC}^{-1}\right.$, Zhang et al., 2005a, b). All these values were within the range of organic mass to organic carbon (OA/OC) ratios of $1.1-1.5 \mu \mathrm{g} \mu \mathrm{gC}^{-1}$ for less water-soluble organics (Turpin and Lim, 2001). The linear regression fit to OOA versus SOC gave a slope of $1.95 \mu \mathrm{g} \mu \mathrm{gC} \mathrm{C}^{-1}$ and an intercept of $4.68 \mu \mathrm{g} \mathrm{m}^{-3}$. This slope was slightly lower than the OOA/OOC (oxygenated organic carbon as the total carbon of OOA) ratios in Tokyo (2.3-2.4 $\mu \mathrm{g} \mu \mathrm{gC}^{-1}$, Kondo et al., 2007) 


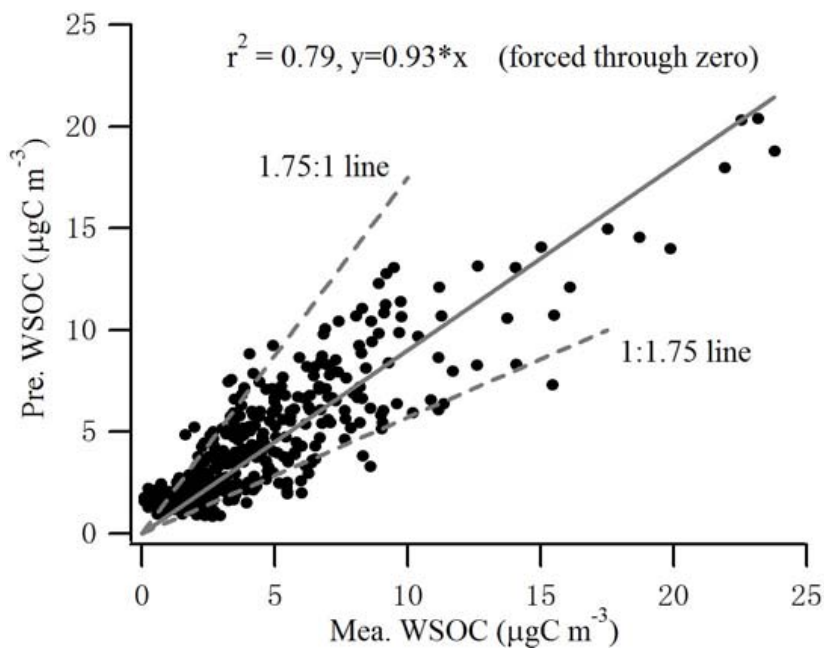

Fig. 16. Scatter plots of predicted versus measured WSOC. The dashed lines represent 1.75:1 and 1:1.75 reference lines.

and in Pittsburgh $\left(2.2 \mu \mathrm{g} \mu \mathrm{gC} \mathrm{C}^{-1}\right.$, Zhang et al., 2005a, b). However, all these values were within the range of OA/OC ratios of $1.5-3.1 \mu \mathrm{g} \mathrm{\mu gC^{-1 }}$ for more water-soluble organics (Turpin and Lim, 2001). The intercept was probably partly due to the presence of oxygenated species in primary emissions.

The relative contributions of $\mathrm{HOA}$ and $\mathrm{OOA}$ between 00:00-24:00, 00:00-08:00, 09:00-18:00, and 19:0024:00 LT, were illustrated in Fig. 13. It was clear that the relative abundance of HOA and OOA varied significantly during different hours of the day, e.g. OOA up to $\sim 80 \%$ of OA mass at fifteen o'clock in the afternoon and HOA up to $55 \%$ of OA mass at four o'clock at night. The average of organic mass spectrum at fifteen o'clock was very similar to that of LVOOA $\left(r^{2}\right.$ as 0.97$)$, indicating that OA mass was dominated by secondary organic aerosol at this time of the day; while the average organic mass spectrum at four o'clock was relatively poorly correlated with that of LV-OOA $\left(r^{2}\right.$ as 0.78$)$ or HOA $\left(r^{2}\right.$ as 0.50$)$, suggesting the presence of both primary and secondary organic aerosol at night. In addition, a new particle formation and growth event (Yue et al., 2010) was observed at the BG site on 21 July, during which OOA accounted for as high as $\sim 93 \%$ of OA mass. Zhang et al. (2004) suggested that extensive condensation of gaseous precursors of OA onto preexisting aerosol particles increases the secondary organic aerosol mass in the nucleation event.

Based on the EC tracer method, secondary organic aerosol (estimated by $1.95 \times \mathrm{SOC}$ ) and primary organic aerosol (equivalent to $1.11 \times$ POC) accounted for $53 \%$ and $47 \%$ of OA mass, respectively. Combining the results from PMF analysis with that from the EC tracer method, it was estimated that primary organic aerosol constituted $\sim 34-47 \%$ of OA mass and secondary organic aerosol constituted $\sim 53-$ $66 \%$ at the BG site during summer reason. The estimates of SOA in this study corresponded well with the results of WSOC (accounting for $\sim 60 \%$ of OC on average) from the same campaign by Miyazaki et al. (2009).

\subsubsection{Comparison between PMF results and WSOC measurements}

A major source of WSOC is secondary organic aerosol (SOA), formed by the oxidation of VOCs followed by condensation on existing particles and/or nucleation (Saxena et al., 1995) when biomass burning contribution is negligible, which is true in this study since $m / z 60$, a typical fragment in AMS spectra of biomass burning aerosol, was at trace levels throughout the study period. The WSOC mass concentrations were highly correlated with OOA $\left(r^{2}\right.$ in the range of $0.86-0.93$ ) in both summer and winter seasons, indicating that they are very similar in chemical characteristics (Kondo et al., 2007). The slopes of OOA versus WSOC are 3.163.31 for these seasons in Tokyo (Kondo et al., 2007). In the current study, two subtypes of WSOC (i.e. $\mathrm{WSOC}_{\mathrm{hpi}}$ and $\mathrm{WSOC}_{\mathrm{hpo}}$ ) and of OOA (i.e. LV-OOA \& and SV-OOA) were obtained, thus the data analysis of these subtypes using different techniques can provide more insights into the chemical nature of secondary organic aerosol in the PRD region.

Time series of the mass concentrations of OOA and WSOC were shown in Fig. 14. WSOC correlated well with OOA $\left(r^{2}=0.71\right)$, better than its correlation with individual OOA components $\left(r^{2}\right.$ as 0.68 for LV-OOA and 0.45 for SVOOA). The correlation between HOA and WSOC was quite weak ( $r^{2}$ as 0.22$)$, as shown in Table 3 , indicating that the contribution of HOA to WSOC was quite insignificant in the PRD region.

The degrees of oxidation and water solubility of OOA varied significantly during different hours of the day (Fig. 15). The slope of OOA versus WSOC (i.e. 1.74) reached the highest level between 09:00-18:00 LT, indicating that secondary organic aerosol particles are more photochemically processed/aged thus more water soluble during the day. This was supported by higher abundance of LV-OOA (68\%) relative to SV-OOA (32\%), since LV-OOA has a higher OA/OC ratio than SV-OOA (Jimenez et al., 2009). Nevertheless, all these slopes (1.27-1.74) were significantly lower than those reported in Tokyo (Kondo et al., 2007), suggesting that submicron organic aerosol in Tokyo were more aged and oxidized than OA in the PRD regional air mass.

WSOC concentrations can be predicted by a multivariate linear regression model with LV-OOA and SV$\mathrm{OOA}$ as independent variables (predicted $\mathrm{WSOC}=0.42 \mathrm{LV}$ $\mathrm{OOA}+0.38 \mathrm{SV}-\mathrm{OOA}+0.29)$ and the predicted values were correlated with the measured WSOC $\left(r^{2}=0.79\right.$, see Fig. 16). The regression coefficients were determined as the water soluble organic carbon contents of LV-OOA and SV-OOA, respectively. Jimenez et al. (2009) suggested that the empirical formulas of LV-OOA and SV-OOA were $\sim \mathrm{C}_{8} \mathrm{O}_{5.5} \mathrm{H}_{10}$ and $\sim \mathrm{C}_{8} \mathrm{O}_{3} \mathrm{H}_{11}$, thus the organic carbon contents of LV-OOA 

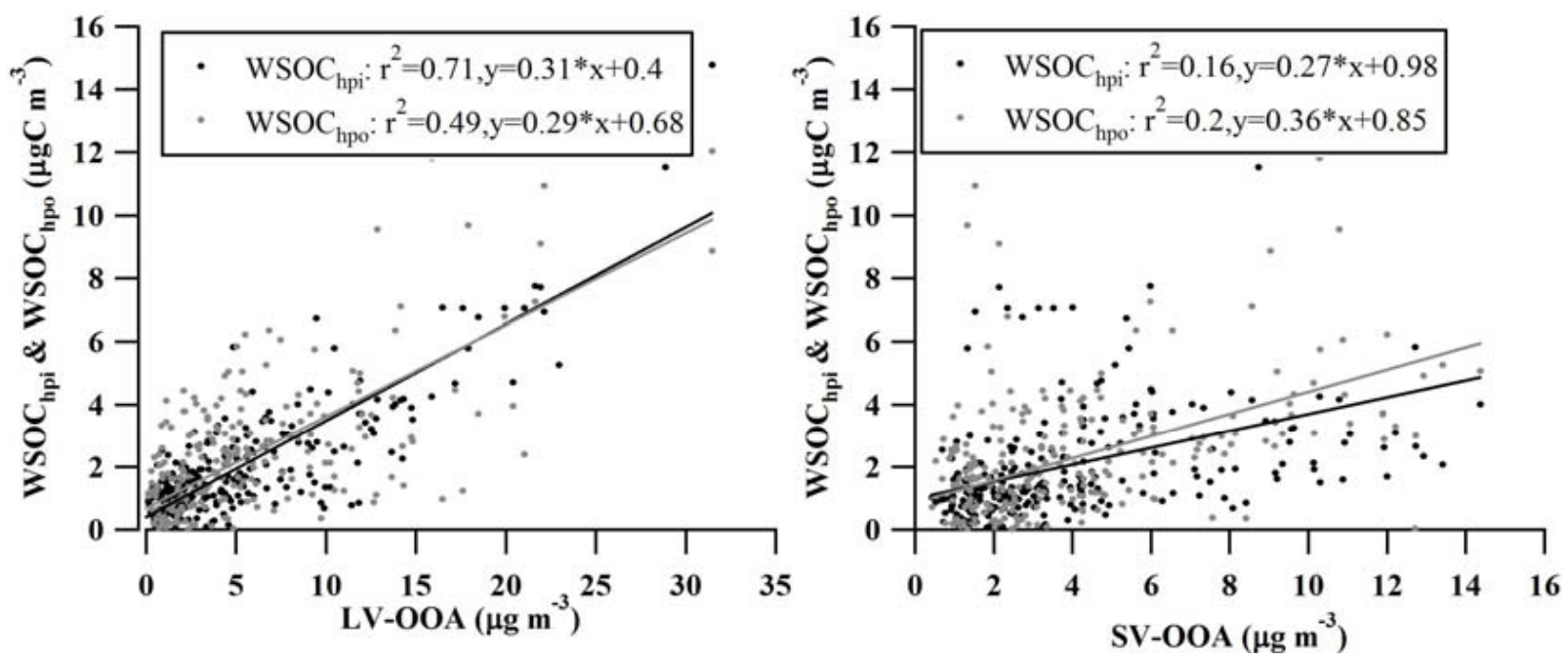

Fig. 17. Scatter plots of WSOChpi, WSOChpo versus LV-OOA, SV-OOA.

and SV-OOA were calculated as 0.49 and 0.62 , respectively. Therefore, approximately $86 \%$ of LV-OOA was estimated as water soluble on the basis of carbon content comparison, and this percentage was close to $88 \%$ in Tokyo (Kondo et al., 2007). On average, approximately $61 \%$ of SV-OOA was estimated as water soluble, which is less than the fraction of LV-OOA.

$\mathrm{WSOC}_{\mathrm{hpi}}$ is highly oxygenated and tends to be highly soluble in water while $\mathrm{WSOC}_{\mathrm{hpo}}$ tends to be less hygroscopic (Miyazaki et al., 2009). Figure 17 showed the scatter plots of $\mathrm{WSOC}_{\mathrm{hpi}}$, $\mathrm{WSOC}_{\mathrm{hpo}}$ versus LV-OOA, SV-OOA. It can be seen that LV-OOA correlates with both $\mathrm{WSOC}_{\mathrm{hpi}}\left(r^{2}\right.$ as 0.71$)$ and $\mathrm{WSOC}_{\mathrm{hpo}}\left(r^{2}\right.$ as 0.49$)$. However, it is apparent that SVOOA is not associated with both $\left(\mathrm{WSOC}_{\mathrm{hpi}}\right.$ and $\mathrm{WSOC}_{\mathrm{hpo}}$ ).

\section{Conclusions}

As part of the PRIDE-PRD 2006 campaign, physical and chemical properties of submicron particles in regional air mass of PRD were investigated in this study by online measurements of size-resolved organics and inorganics (sulfate, nitrate, ammonium, and chloride) by high-time resolution AMS (10 min), WSOC (6 min), EC and OC (1 h) at the rural BG site during July 2006. Samples apparently impacted by strong local emissions or heavy rainfall after typhoons were removed from this analysis.

Approximately $82 \%$ of regional submicron particles in PRD were composed of organics and sulfate with the average mass concentration as $11.8 \mu \mathrm{g} \mathrm{m}^{-3}$ and $13.5 \mu \mathrm{g} \mathrm{m}^{-3}$, respectively. These levels were significantly higher than those reported in other locations, indicating the severe air pollution of submicron particles in PRD. During the one-month study period, four categories of air masses at the BG site were identified, and submicron aerosol characteristics var- ied greatly with air mass category. It is interesting to find in this study that in the air mass from Southeast-South, when the BG site was downwind of PRD urban areas and impacted by the urban plume, both organics and sulfate exhibited clear bimodal size distributions with the first mode peaking at $D_{\mathrm{va}}$ around $200 \mathrm{~nm}$ and the second mode occurring around $300-700 \mathrm{~nm}$. With the mass spectra information from AMS measurements, the first mode organics was found to be contributed by both secondary organic formation and combustion-related primary emissions, which is different from previous finding that the first mode was mainly attributed by combustion sources. The submicron particles in the Southeast-South air mass category, under the apparent influence of upwind PRD urban emissions, were different from particles in other air mass categories, not only reflected by the bimodal size distributions but also by the acidity of these particles.

With the PMF model, organics from AMS spectral data were characterized into three components including HOA, SV-OOA and LV-OOA. HOA was primarily from primary combustion-related emissions according to its AMS mass spectra and exhibited significant positive correlations with EC as well as POC estimated by the EC tracer method. The presence of abundant $m / z 44$ in SV-OOA and LV-OOA indicated the dominance of oxygenated species in these two components. Strong correlations between SV-OOA and nitrate and between LV-OOA and sulfate as well as their distinct diurnal variation patterns suggested that SV-OOA and LVOOA were of secondary in origin but LV-OOA was less volatile. In addition, OOA (SV-OOA plus LV-OOA) was highly correlated with secondary organic carbon, which is the difference between OC and POC from the EC tracer method. 
This study revealed that secondary organic aerosol dominated submicron particles at the BG site, ranging from 53$66 \%$ of OC mass, based on the estimates from two independent methods (PMF and the EC tracer method). This estimate agreed quite well with WSOC results, which accounted for about $60 \%$ of OC during the study period. On the basis of carbon content, about $86 \%$ of LV-OOA was found water soluble compared to $61 \%$ for SV-OOA, indicating that the characteristics of LV-OOA were more aged and oxygenated, relatively enriched during the day, less volatile, and more water soluble than SV-OOA in the PRD regional air mass.

Acknowledgements. This research was supported by the $\mathrm{Na}$ tional High Technology Research and Development Program of China (2006AA06A306), the China National Basic Research and Development Programs 2002CB410801 and the European Union's Seventh Framework Programme (FP7/2007-2013, Grant No. 212095). This work was also supported by the Ministry of Education, Culture, Sports, Science, and Technology (MEXT) and the global environment research fund of the Japanese Ministry of the Environment (B-083). The authors would like to thank the China Scholarship Council for the scholarship supporting R. Xiao at the University of Tokyo, Japan.

Edited by: S. C. Liu

\section{References}

Alfarra, M. R., Coe, H., Allan, J. D., Bower, K. N., Boudries, H., Canagaratna, M. R., Jimenez, J. L., Jayne, J. T., Garforth, A., Li, S. M., and Worsnop, D. R.: Characterization of urban and regional organic aerosols in the lower Fraser Valley using two Aerodyne Aerosol Mass Spectrometers, Atmos. Environ., 38, 5745-5758, 2004.

Alfarra, M. R., Prevot, A. S. H., Szidat, S., Sandradewi, J., Weimer, S., Lanz, V. A., Schreiber, D., Mohr, M., and Baltensperger, U.: Identification of the mass spectral signature of organic aerosols from wood burning emissions, Environ. Sci. Technol., 41, 57705777, 2007.

Allan, J. D., Alfarra, M. R., Bower, K. N., Williams, P. I., Gallagher, M. W., Jimenez, J. L., McDonald, A. G., Nemitz, E., Canagaratna, M. R., Jayne, J. T., Coe, H., and Worsnop, D. R.: Quantitative sampling using an aerodyne aerosol mass spectrometer: 2. Measurements of fine particulate chemical composition in two UK cities, J. Geophys. Res., 108(D3), 4091, doi:10.1029/2002JD002359, 2003a.

Allan, J. D., Jimenez, J. L., Williams, P. I., Alfarra, M. R., Bower, K. N., Jayne, J. T., Coe, H., and Worsnop, D. R.: Quantitative sampling using an aerodyne aerosol mass spectrometer: 1 . Techniques of data interpretation and error analysis, J. Geophys. Res., 108(D3), 4090, doi:10.1029/2002JD002358, 2003b.

Allan, J. D., Bower, K. N., Coe, H., Boudries, H., Jayne, J. T., Canagaratna, M. R., Millet, D. B., Goldstein, A. H., Quinn, P. K., Weber, R. J., and Worsnop, D. R.: Submicron aerosol composition at Trinidad Head, California, during ITCT 2K2: its relationship with gas phase volatile organic carbon and assessment of instrument performance, J. Geophys. Res., 109, D23S24, doi:10.1029/2003JD004208, 2004.
Cabada, J. C., Pandis, S. N., and Robinson, A. L.: Sources of atmospheric carbonaceous particulate matter in Pittsburgh, Pennsylvania, J. Air Waste Manag. Assoc., 52(6), 732-741, 2002.

Cabada, J. C., Pandis, S. N., Subramanian, R., Robinson, A. L., Polidori, A., and Turpin, B.: Estimating the secondary organic aerosol contribution to $\mathrm{PM}_{2.5}$ using the EC tracer method, Aerosol Sci. and Technol., 38(S1), 140-155, 2004.

Cao, J. J., Lee, S. C., Ho, K. F., Zhang, X. Y., Zou, S. C., Fung, K., Chow, J. C., and Watson, J. G.: Characteristics of carbonaceous aerosol in Pearl River Delta Region, China during 2001 winter period, Atmos. Environ., 37, 1451-1460, 2003.

Cao, J. J., Lee, S. C., Ho, K. F., Zou, S. C., Fung, K., Li, Y., Watson, J. G., and Chow, J. C.: Spatial and seasonal variations of atmospheric organic carbon and elemental carbon in Pearl River Delta Region, China, Atmos. Environ., 38, 4447-4456, 2004.

Cheng, Y. F., Eichler, H., Wiedensohler, A., Heintzenberg, J., Zhang, Y. H., Hu, M., Herrmann, H., Zeng, L. M., Liu, S., Gnauk, T., Bruggemann, E., and He, L. Y.: Mixing state of elemental carbon and non-light-absorbing aerosol components derived from in situ particle optical properties at Xinken in Pearl River Delta of China, J. Geophys. Res., 111, D20204, doi:10.1029/2005JD006929, 2006.

Cheng, Y. F., Wiedensohler, A., Eichler, H., Heintzenberg, J., Su, H., Gnauk, T., Bruggemann, E., Herrmann, H., Slanina, J., Zeng, L. M., Tuch, T., Liu, S., and Zhang, Y. H.: Aerosol optical properties and related chemical apportionment at Xinken in Pearl River Delta of China, Atmos. Environ., 42(25), 6351-6372, 2008.

Dechapanya, W., Russell, M., and Allen, D. T.: Estimates of anthropogenic secondary organic aerosol formation in Houston, Texas, Aerosol Sci. Technol., 38(S1), 156-166, 2004.

Fan, S. J., Fan, Q., Yu, W., Luo, X. Y., Wang, B. M., Song, L. L., and Leong, K. L.: Atmospheric boundary layer characteristics over the Pearl River Delta, China during summer 2006: measurement and model results, Atmos. Chem. Phys. Discuss., 11, 4807-4842, doi:10.5194/acpd-11-4807-2011, 2011.

Garland, R. M., Yang, H., Schmid, O., Rose, D., Nowak, A., Achtert, P., Wiedensohler, A., Takegawa, N., Kita, K., Miyazaki, Y., Kondo, Y., Hu, M., Shao, M., Zeng, L. M., Zhang, Y. H., Andreae, M. O., and Pöschl, U.: Aerosol optical properties in a rural environment near the mega-city Guangzhou, China: implications for regional air pollution, radiative forcing and remote sensing, Atmos. Chem. Phys., 8, 5161-5186, doi:10.5194/acp-85161-2008, 2008.

Hagler, G. S. W., Bergin, M. H., Salmon, L. G., Yu, J. Z., Wan, E. C. H., Zheng, M., Zeng, L. M., Kiang, C. S., Zhang, Y. H., Lau, A. K. H., and Schauer, J. J.: Source areas and chemical composition of fine particulate matter in the Pearl River Delta region of China, Atmos. Environ., 40, 3802-3815, 2006.

Hering, S. V. and Friedlander, S. K.: Origins of aerosol sulfur size distributions in the Los Angeles basin, Atmos. Environ., 16(11), 2647-2656, 1982.

Hering, S. V., Eldering, A., and Seinfeld, J. H.: Bimodal character of accumulation mode aerosol mass distributions in southern California, Atmos. Environ., 31(1), 1-11, 1997.

Hofzumahaus, A., Rohrer, F., Lu, K., Bohn, B., Brauers, T., Chang, C. C., Fuchs, H., Holland, F., Kita, K., Kondo, Y., Li, X., Lou, S., Shao, M., Zeng, L. M., Wahner, A., Zhang, Y. H.: Amplified Trace Gas Removal in the Troposphere, Science, 324(5935), 
1702-1704, doi:10.1126/science.1164566, 2009.

Hua, W., Chen, Z. M., Jie, C. Y., Kondo, Y., Hofzumahaus, A., Takegawa, N., Chang, C. C., Lu, K. D., Miyazaki, Y., Kita, K., Wang, H. L., Zhang, Y. H., and Hu, M.: Atmospheric hydrogen peroxide and organic hydroperoxides during PRIDE-PRD'06, China: their concentration, formation mechanism and contribution to secondary aerosols, Atmos. Chem. Phys., 8, 6755-6773, doi:10.5194/acp-8-6755-2008, 2008.

Jayne, J. T., Leard, D. C., Zhang, X., Davidovits, P., Smith, K. A., Kolb, C. E., and Worsnop, D. R.: Development of an aerosol mass spectrometer for size and composition analysis of submicron particles, Aerosol Sci. Technol., 33, 49-70, 2000.

Jimenez, J. L., Jayne, J. T., Shi, Q., Kolb, C. E., Worsnop, D. R., Yourshaw, I., Seinfeld, J. H., Flagan, R. C., Zhang, X. F., Smith, K. A., Morris, J. W., and Davidovits, P.: Ambient aerosol sampling using the aerodyne aerosol mass spectrometer, J. Geophys. Res., 108(D7), 8425, doi:10.1029/2001JD001213, 2003.

Jimenez J. L., Canagaratna M. R., Donahue N. M., Prevot, A. S. H., Zhang, Q., Kroll, J. H., DeCarlo, P. F., Allan, J. D., Coe, H., Ng, N. L., Aiken, A. C., Docherty, K. S., Ulbrich, I. M., Grieshop, A. P., Robinson, A. L., Duplissy, J., Smith, J. D., Wilson, K. R., Lanz, V. A., Hueglin, C., Sun, Y. L., Tian, J., Laaksonen, A., Raatikainen, T., Rautiainen, J., Vaattovaara, P., Ehn, M., Kulmala, M., Tomlinson, J. M., Collins, D. R., Cubison, M. J., Dunlea, E. J., Huffman, J. A., Onasch, T. B., Alfarra, M. R., Williams, P. I., Bower, K., Kondo, Y., Schneider, J., Drewnick, F., Borrmann, S., Weimer, S., Demerjian, K., Salcedo, D., Cottrell, L., Griffin, R., Takami, A., Miyoshi, T., Hatakeyama, S., Shimono, A., Sun, J. Y., Zhang, Y. M., Dzepina, K., Kimmel, J. R., Sueper, D., Jayne, J. T., Herndon, S. C., Trimborn, A.M., Williams, L. R., Wood, E. C., Middlebrook, A. M., Kolb, C. E., Baltensperger, U., and Worsnop, D. R.: Evolution of organic aerosols in the atmosphere, Science, 326, 1525, doi:10.1126/science.1180353, 2009.

Kondo, Y., Miyazaki, Y., Takegawa, N., Miyakawa, T., Weber, R. J., Jimenez, J. L., Zhang, Q., and Worsnop, D. R.: Oxygenated and water-soluble organic aerosols in Tokyo, J. Geophys. Res., 112, D01203, doi:10.1029/2006JD007056, 2007.

Lanz, V. A., Alfarra, M. R., Baltensperger, U., Buchmann, B., Hueglin, C., and Prévôt, A. S. H.: Source apportionment of submicron organic aerosols at an urban site by factor analytical modelling of aerosol mass spectra, Atmos. Chem. Phys., 7, 1503-1522, doi:10.5194/acp-7-1503-2007, 2007.

Lanz, V. A., Alfarra, M. R., Baltensperger, U., Buchmann, B., Hueglin, C., Szidat, S., Wehrli, M. N., Wacker, L., Weimer, S., Caseiro, A., Puxbaum, H., and Prevot, A. S. H.: Source Attribution of Submicron Organic Aerosols during Wintertime Inversions by Advanced Factor Analysis of Aerosol Mass Spectra, Environ. Sci. Technol., 42, 214-220, doi:10.1021/es0707207, 2008.

Lee, C. S. L. and Li, X. D.: Heavy metals and Pb isotopic composition of aerosols in urban and suburban areas of Hong Kong and Guangzhou, South China - Evidence of the long-range transport of air contaminants, Atmos. Environ., 41(2), 432-447, 2007.

Li, X., Brauers, T., Shao, M., Garland, R. M., Wagner, T., Deutschmann, T., and Wahner, A.: MAX-DOAS measurements in southern China: retrieval of aerosol extinctions and validation using ground-based in-situ data, Atmos. Chem. Phys., 10, 20792089, doi:10.5194/acp-10-2079-2010, 2010.

Liu, S., Hu, M., Slanina, S., He, L., Niu, Y., Bruegemann, E., Gnauk, T., and Herrmann, H.: Size distribution and source anal- ysis of ionic compositions of aerosols in polluted periods at Xinken in Pearl River Delta (PRD) of China, Atmos. Environ., 42, 6284-6295, 2008.

Liu, X. G., Cheng, Y. F., Zhang, Y. H., Jung, J. S., Sugimoto, N., Chang, S. Y., Kim, Y. J., Fan, S. J., and Zeng, L. M.: Influences of relative humidity and particle chemical composition on aerosol scattering properties during the 2006 PRD campaign, Atmos. Environ., 42(7), 1525-1536, 2008.

Lou, S., Holland, F., Rohrer, F., Lu, K., Bohn, B., Brauers, T., Chang, C.C., Fuchs, H., Hseler, R., Kita, K., Kondo, Y., Li, X., Shao, M., Zeng, L., Wahner, A., Zhang, Y., Wang, W., and Hofzumahaus, A.: Atmospheric $\mathrm{OH}$ reactivities in the Pearl River Delta - China in summer 2006: measurement and model results, Atmos. Chem. Phys., 10, 11243-11260, doi:10.5194/acp10-11243-2010, 2010.

Lu, K. D., Zhang, Y. H., Su, H., Shao, M., Zeng, L. M., Zhong, L. J., Xiang, Y. R., Chang, C. C., Chou, C. K. C., and Wahner, A.: Regional ozone pollution and key controlling factors of photochemical ozone production in Pearl River Delta during summer time, Sci. China Chem., 53(3), 651-663, 2010.

McMurry, P. H.: A Review of atmospheric aerosol measurements, Atmos. Environ., 34(12), 1959-1999, 2000.

Meng, Z. and Seinfeld, J. H.: On the source of the submicrometer droplet mode of urban and regional aerosols, Aerosol Sci. Technol., 20(3), 253-265, 1994.

Middlebrook, A. M., Murphy, D. M., Lee, S. H., Thomson, D. S., Prather, K. A., Wenzel, R. J., Liu, D. Y., Phares, D. J., Rhoads, K. P., Wexler, A. S., Johnston, M. V., Jimenez, J. L., Jayne, J. T., Worsnop, D. R., Yourshaw, I., Seinfeld, J. H., and Flagan, R. C.: An intercomparison of particle mass spectrometers during the 1999 Atlanta Supersite Project, J. Geophys. Res., 108(D7), 8424, doi:10.1029/2001JD000660, 2003.

Miyakawa, T., Takegawa, N., and Kondo, Y.: Photochemical evolution of submicron aerosol chemical composition in the Tokyo megacity in summer, J. Geophys. Res., 113, D14304. doi:10.1029/2007JD009493, 2008.

Miyazaki, Y., Kondo, Y., Shiraiwa, M., Takegawa, N., Miyakawa, T., Han, S., Kita, K., Hu, M., Deng, Z. Q., Zhao, Y., Sugimoto, N., Blake, D. R., and Weber, R. J.: Chemical characterization of water-soluble organic carbon aerosols at a rural site in the Pearl River Delta, China, in the summer of 2006, J. Geophys. Res., 114, D14208, doi:10.1029/2009JD011736, 2009.

Paatero, P.: Least squares formulation of robust non-negative factor analysis, Chemometr. Intell. Lab. Syst., 37, 23-35, 1997.

Paatero, P. and Tapper, U.: Positive matrix factorization: a nonnegative factor model with optimal utilization of error estimates of data values, Environmetrics, 5, 111-126, 1994.

Rose, D., Nowak, A., Achtert, P., Wiedensohler, A., Hu, M., Shao, M., Zhang, Y., Andreae, M. O., and Pöschl, U.: Cloud condensation nuclei in polluted air and biomass burning smoke near the mega-city Guangzhou, China Part 1: Size-resolved measurements and implications for the modeling of aerosol particle hygroscopicity and CCN activity, Atmos. Chem. Phys., 10, 33653383, doi:10.5194/acp-10-3365-2010, 2010.

Salcedo, D., Onasch, T. B., Dzepina, K., Canagaratna, M. R., Zhang, Q., Huffman, J. A., DeCarlo, P. F., Jayne, J. T., Mortimer, P., Worsnop, D. R., Kolb, C. E., Johnson, K. S., Zuberi, B., Marr, L. C., Volkamer, R., Molina, L. T., Molina, M. J., Cardenas, B., Bernabé, R. M., Márquez, C., Gaffney, J. S., Marley, 
N. A., Laskin, A., Shutthanandan, V., Xie, Y., Brune, W., Lesher, R., Shirley, T., and Jimenez, J. L.: Characterization of ambient aerosols in Mexico City during the MCMA-2003 campaign with Aerosol Mass Spectrometry: results from the CENICA Supersite, Atmos. Chem. Phys., 6, 925-946, doi:10.5194/acp-6-9252006, 2006.

Saxena, P., Hildemann, L. M., McMurry, P. H., and Seinfeld, J. H.: Organics alter hygroscopic behavior of atmospheric particles, J. Geophys. Res., 100, 18755-18770, 1995.

Seinfeld, J. H. and Pandis, S. N.: Atmospheric Chemistry and Physics, John Wiley \& Sons, Inc., New Jersey, 2006.

Seinfeld, J. H. and Pankow, J. F.: Organic atmospheric particulate material, Annu. Rev. Phys. Chem., 54, 121-140, 2003.

Shao, M., Huang, D., Gu, D., Lu, S., Chang, C., and Wang, J.: Estimate of anthropogenic halocarbon emission based on measured ratio relative to $\mathrm{CO}$ in the Pearl River Delta region, China, Atmos. Chem. Phys., 11, 5011-5025, doi:10.5194/acp-11-50112011, 2011.

Sun, J., Zhang, Q., Canagaratna, M. R., Zhang, Y., Ng, N. L., Sun, Y., Jayne, J. T., Zhang, X., Zhang, X., and Worsnop, D. R.: Highly time- and size-resolved characterization of submicron aerosol particles in Beijing using an Aerodyne Aerosol Mass Spectrometer, Atmos. Environ., 44, 131-140, 2010.

Takami, A., Miyoshi, T., Shimono, A., and Hatakeyama, S.: Chemical composition of fine aerosol measured by AMS at Fukue Island, Japan during APEX period, Atmos. Environ., 39, 49134924, 2005.

Takegawa, N., Miyazaki, Y., Kondo, Y., Komazaki, Y., Miyakawa, T., Jimenez, J. L., Jayne, J. T., Worsnop, D. R., Allan, J. D., and Weber, R. J.: Characterization of an aerodyne aerosol mass spectrometer (AMS): intercomparison with other aerosol instruments, Aerosol Sci. Technol., 39(8), 760-770, 2005.

Takegawa, N., Miyakawa, T., Kondo, Y., Jimenez, J. L., Zhang, Q., Worsnop, D. R., and Fukuda, M.: Seasonal and diurnal variations of submicron organic aerosol in Tokyo observed using the Aerodyne aerosol mass spectrometer, J. Geophys. Res., 111, D11206, doi:10.1029/2005JD006515, 2006.

Takegawa, N., Miyakawa, T., Watanabe, M., Kondo, Y., Miyazaki, Y., Han, S., Zhao, Y., Pinxteren, D., van, Bruggemann, E., Gnauk, T., Herrmann, H., Xiao, R., Deng, Z., Hu, M., Zhu, T., and Zhang, Y.: Performance of an aerodyne aerosol mass spectrometer (AMS) during intensive campaigns in China in the summer of 2006, Aerosol Sci. Technol., 43, 189-204, 2009.

Topping, D., Coe, H., McFiggans, G., Burgess, R., Allan, J., Alfarra, M. R., Bower, K., Choularton, T. W., Decesari, S., and Facchini, M. C.: Aerosol chemical characteristics from sampling conducted on the Island of Jeju, Korea during ACE Asia, Atmos. Environ., 38(14), 2111-2123, 2004.

Turpin, B. J. and Huntzicker, J. J.: Identification of secondary aerosol episodes and quantification of primary and secondary organic aerosol concentrations during SCAQS, Atmos. Environ., 29, 3527-3544, 1995.

Turpin, B. J. and Lim, H. J.: Species contributions to PM $_{2.5}$ mass concentrations: Revisiting common assumptions for estimating organic mass, Aerosol Sci. Technol., 35, 602-610, 2001.

Ulbrich, I. M., Lechner, M., and Jimenez, J. L.: AMS Spectral Database, online available at: http://cires.colorado.edu/ jimenez-group/AMSsd, last access: 29 June 2011, 2007.

Ulbrich, I. M., Canagaratna, M. R., Zhang, Q., Worsnop, D. R., and
Jimenez, J. L.: Interpretation of organic components from Positive Matrix Factorization of aerosol mass spectrometric data, Atmos. Chem. Phys., 9, 2891-2918, doi:10.5194/acp-9-2891-2009, 2009.

Weimer, S., Drewnick, F., and Hogrefe, O.: Size-selective nonrefractory ambient aerosol measurements during the particulate matter technology assessment and characterization study-New York 2004 winter intensive in New York, J. Geophys. Res., 111, D18305, doi:10.1029/2006JD007215, 2006.

Xiao, R., Takegawa, N., Kondo, Y., Miyazaki, Y., Miyakawa, T., Hu, M., Shao, M., Zeng, L. M., Hofzumahaus, A., Holland, F., Lu, K., Sugimoto, N., Zhao, Y., and Zhang, Y. H.: Formation of submicron sulfate and organic aerosols in the outflow from the urban region of the Pearl River Delta in China, Atmos. Environ., 43, 3754-3763, 2009.

Yao, X., Fang, M., and Chan, C. K.: Size distributions and formation of dicarboxylic acids in atmospheric particles, Atmos. Environ., 36, 2099-2107, 2002.

Yao, X., Lau, A. P. S., Fang, M., Chan, C. K., and Hu, M.: Size distributions and formation of ionic species in atmospheric particulate pollutants in Beijing, China: 1-inorganic ions, Atmos. Environ., 37, 2991-3000, 2003a.

Yao, X., Lau, A. P. S., Fang, M., Chan, C. K., and Hu, M.: Size distributions and formation of ionic species in atmospheric particulate pollutants in Beijing, China: 2-dicarboxylic acids, Atmos. Environ., 37, 3001-3007, 2003 b.

Yue, D. L., Hu, M., Wu, Z. J., Guo, S., Wen, M. T., Nowak, A., Wehner, B., Wiedensohler, A., Takegawa, N., Kondo, Y., Wang, X. S., Li, Y. P., Zeng, L. M., and Zhang, Y. H.: Variation of particle number size distributions and chemical compositions at the urban and downwind regional sites in the Pearl River Delta during summertime pollution episodes, Atmos. Chem. Phys., 10, 9431-9439, doi:10.5194/acp-10-9431-2010, 2010.

Zhang, Q., Stanier, C. O., Canagaratna, M. R., Jayne, J. T., Worsnop, D. R., Pandis, S. N., and Jimenez, J. L.: Insights into the chemistry of new particle formation and growth events in Pittsburgh based on aerosol mass spectrometry, Environ. Sci. Technol., 38(18), 4797-4809, 2004.

Zhang, Q., Alfarra, M. R., Worsnop, D. R., Allan, J. D., Coe, H., Canagaratna, M. R., and Jimenez, J. L.: Deconvolution and quantification of hydrocarbon-like and oxygenated organic aerosols based on aerosol mass spectrometry, Environ. Sci. Technol., 39, 4938-4952, 2005a.

Zhang, Q., Worsnop, D. R., Canagaratna, M. R., and Jimenez, J. L.: Hydrocarbon-like and oxygenated organic aerosols in Pittsburgh: insights into sources and processes of organic aerosols, Atmos. Chem. Phys., 5, 3289-3311, doi:10.5194/acp-5-32892005, 2005 b.

Zhang, Q., Canagaratna, M. R., Jayne, J. T., Worsnop, D. R., and Jimenez, J. L.: Time and size-resolved chemical composition of submicron particles in Pittsburgh: implications for aerosol sources and processes, J. Geophys. Res., 110, D07S09, doi:10.1029/2004JD004649, 2005c.

Zhang, Q., Jimenez, J. L., Canagaratna, M. R., Allan, J. D., Coe, H., Ulbrich, I., Alfarra, M. R., Takami, A., Middlebrook, A. M., Sun, Y. L., Dzepina, K., Dunlea, E., Docherty, K., DeCarlo, P. F., Salcedo, D., Onasch, T., Jayne, J. T., Miyoshi, T., Shimono, A., Hatakeyama, S., Takegawa, N., Kondo, Y., Schneider, J., Drewnick, F., Borrmann, S., Weimer, S., Demer- 
jian, K., Williams, P., Bower, K., Bahreini, R., Cottrell, L., Griffin, R. J., Rautiainen, J., Sun, J. Y., Zhang, Y. M., and Worsnop, D. R.: Ubiquity and dominance of oxygenated species in organic aerosols in anthropogenically-influenced Northern Hemisphere midlatitudes, Geophys. Res. Lett., 34, L13801, doi:10.1029/2007GL029979, 2007.

Zhang, Y. H., Zhu, X. L., Slanina, S., Shao, M., Zeng, L. M., Hu, M., Bergin, M., and Salmon, L.: Aerosol pollution in some Chinese cities. Pure Appl. Chem., 76(6), 1227-1239, 2004.

Zhang, Y. H., Hu, M., Zhong, L. J., Wiedensohler, A., Liu, S. C., Andreae, M. O., Wang, W., and Fan, S. J.: Regional integrated experiments on air quality over Pearl River Delta 2004 (PRIDEPRD2004): Overview, Atmos. Environ., 42, 6157-6173, 2008.
Zheng, M., Kester, D. R., Wang, F., Shi, X., and Guo, Z.: Size distributions of organic and inorganic species in Hong Kong aerosols during the wet and dry seasons, J. Geophys. Res., 113, D16303, doi:10.1029/2007JD009494, 2008.

Zheng, M., Wang, F., Hagler, G. S. W., Hou, X., Bergin, M. H., Cheng, Y., Salmon, L. G., Schauer, J. J., Louie, P. K. K., Zeng, L., and Zhang, Y.: Sources of excess urban carbonaceous aerosol in the Pearl River Delta Region, China, Atmos. Environ., 45, 1175-1182, 2011

Zhuang, H., Chan, C. K., Fang, M., and Wexler, A. S.: Size distributions of particulate sulfate, nitrate and ammonium at a coastal site in Hong Kong, Atmos. Environ., 33, 843-853, 1999. 